\title{
Gastric Cancer Immunotherapy: An Overview
}

\author{
Fabrizio Romano*, Fabio Uggeri, Luca Nespoli, Luca Gianotti, Mattia Garancini, Matteo Maternini, \\ Angelo Nespoli, Franco Uggeri
}

Department of Surgery, San Gerardo Hospital, University of Milano-Bicocca, Monza, Italy.

Email: *fabrizio.romano@unimib.it, fabriziorom@hotmail.com

Received April 22 $2^{\text {nd }}, 2013$; revised May 20 $0^{\text {th }}, 2013$; accepted May 30 $30^{\text {th }}, 2013$

Copyright (C) 2013 Fabrizio Romano et al. This is an open access article distributed under the Creative Commons Attribution License, which permits unrestricted use, distribution, and reproduction in any medium, provided the original work is properly cited.

\begin{abstract}
Gastric adenocarcinoma is the third most common cancer and the second most common cause of death due to cancer worldwide. Surgery is still the major prognostic factor for gastric cancer. Patients who could not be resected have a poor prognosis with survival ranging from 3 to 11 months. There is evidence that surgical operations can cause a variety of immunological disturbances in man both in vivo and in vitro. The postoperative changes in the systemic immune response are proportional to the degree of surgical trauma leading to a generalized state of immunosuppression, which is implicated in the development of septic complications and provided a "fertile soil" for tumor cell metastasis. Immunotherapy may be a potentially promising alternative strategy for gastric cancer. In early clinical trials, systemic immunotherapy included both active vaccination directed against defined tumor-associated antigens expressed in gastric carcinoma cells and passive administration of IL-2 with some evidence of regression of metastatic gastric cancer. Other studies have applied immunotherapy in the adjuvant setting with equally promising results. For example, OK-432, a streptococcal preparation, demonstrated marginal improvement in survival for patients with stage III gastric cancer and a meta-analysis of centrally randomized controlled clinical trials indicated a significant survival benefit with combination OK-432 and chemotherapy compared to chemotherapy alone $(p<0.05)$. Additional data suggesting a biological and clinical benefit of subcutaneous, preoperative administration of low-dose IL-2 in colon cancer encouraged us to evaluate low-dose IL-2 therapy in the neoadjuvant setting for patients with gastric adenocarcinoma who undergo surgery and to evaluate its effects on systemic and tumor infiltrating lymphocyte numbers. We also sought to determine if neoadjuvant low-dose IL-2 could influence the clinical outcome for patients undergoing gastric resection for cancer. We report the biological, histological and clinical results with the full accrual of patients and a median follow-up of 51 months.
\end{abstract}

Keywords: Gastric Cancer; Immunotherapy; IL-2

\section{Introduction}

\subsection{Incidence and Risk Factors}

A global cancer statistic made in 2002 [1] refers an incidence of gastric cancer of $8.6 \%$ worldwide $(934,000$ new cases per year in 2002), which poses it in fourth place behind cancers of the lung, breast, colon and rectum. It is still the second most common cause of death from cancer worldwide (700,000 deaths annually). Almost two-thirds of the cases occur in developing countries and $42 \%$ in China alone. The geographical distribution of stomach cancer has wide international variations; high-risk areas include East Asia (China, Japan), Eastern Europe, and parts of Central and South America. Survival for stomach

${ }^{*}$ Corresponding author. cancer is moderately good only in Japan (52\%), where mass screening has been practiced since the 1960s. Survival is also relatively high in North America, possibly due to early diagnosis following a greater number of endoscopic examinations performed for gastric disorders.

The evidence linking Helicobacter pylori infection to cancer of the stomach was considered sufficient by IARC [2] to classify this bacterium as carcinogenic in humans. Its action is probably indirect by provoking gastritis, gastric atrophy, metaplasia, and dysplasia. Helicobacter pylori has an high prevalence worldwide with a relatively small variation, which suggests than other factors are of major importance in gastric cancer pathogenesis. Diet certainly plays an important role: preserved salted foods are high risky. Tobacco smoking has also been clearly accepted as increasing the risk of stomach cancer [3]. 
Even if the incidence of gastric cancer is decreasing worldwide, recent reports referred that tumors of the cardia are on the rise, especially among males and notably in the UK, Ireland, Northern Europe, Australia and New Zealand, China, and North America [4-8]. The rate at which the incidence of proximal stomach cancers has risen exceeds that of any other cancer [8,9]. The increase in tumors of the cardia is taking place principally in countries with relatively low overall rates of gastric cancer. Proximal tumors are associated with higher social class. Helicobacter pylori in these cases seem to play a smaller role.

\subsection{Staging, Surgical Resection and Lymphnodes Dissection}

For those patients with gastric cancer who undergo surgery, the factors that affect prognosis are the location of the tumor, the gross pathologic type and the TNM classification [8]. There are currently 2 major staging systems for patients with gastric cancer. The Japanese use an elaborate system that focuses on a complex anatomic nodal classification scheme. Western countries have adopted a system developed jointly by the American Joint Committee on Cancer (AJCC) and the International Union Against Cancer (UICC) $[10,11]$. In 2002, the AJCC and UICC agreed on a common staging system changing from a nodal staging system based on distance from the primary tumor to a staging system based on the number of positive nodes. Approximately one-third of gastric cancer patients have stage I or II disease at the time of diagnosis. One-quarter have stage III disease, and the remaining $40 \%$ stage IV disease [12]. Estimated adjusted survival 5-year survival after surgery is $82.9 \%$ for stage I, $62.8 \%$ for stage II, $17.8 \%$ for stage III and 3.3\% for stage IV [13]. One-year survival rates are $50 \%$ in stage IIIA and B disease, and $<25 \%$ in stage IV disease. The development of endoscopic techniques has improved the proportion of gastric cancers detected at an early stage.

Surgical resection remains the primary treatment for gastric cancer. Patients who could not be resected have a poor prognosis with survival ranging from 3 to 11 months. Poor prognosis may result by the fact that when the symptoms occur, the cancer has already spread and only a few percentages of patients are eligible for surgery. The aim of surgery is to remove completely the grossly visible tumor and obtain histologically free surgical margins (R0 resection). Only a complete-R0-resection can improve prognosis. The extension of gastric resection depends on the location of the tumor. In our experience total gastrectomy is preferred to partial gastrectomy when tumors are localized to the cardia. Reconstruction of digestive continuity is then realized by Billroth II termino-lateral gastro-digiunal anastomosis in the case of partial gastrectomy and by termino-lateral esophago-di- giunal anastomosis with digiunal loop in case of total gastrectomy.

Lymphnodes dissection is a debated issue in management of gastric cancer. The question of whether the use of a large limphonodes dissection (D2-D4 resection) increases cure rate when compared with limited lymphadenectomy of the perigastric nodes (D1 resection) remains open. A factor which compromises any study comparing survival in patients treated with extensive versus standard lymph node dissections is the "stage migration effect". This is based on the fact that more lymph nodes examined, the greater the probability of positive nodes. For example, some authors reported that up to $75 \%$ of patients classified as stage IIIB on D1 dissection were reclassified as stage IV on D2 dissection [14]. The best method to assess effect of surgery on survival is to compare intermediate stage patients (T3 tumors) regardless of the nodal status. This group would be most likely to benefit from extended lymph node resections. For example, the Memorial Sloan-Kettering Cancer Center reviewed their results in 774 patients who had undergone curative gastric resections [15]. They reported survival rates in patients with T3 tumors treated with D2 and D1 dissections of $54 \%$ and $39 \%$, respectively. They concluded that D2 dissection offered a survival advantage for T3 tumors. Other large randomized studies have compared D1 and D2 resections in patients with gastric cancer and had reached nearly identical conclusions that D2 resections offered no survival advantage and were accomplished at the expense of greater operative morbidity and mortality $[16,17]$. Recently the Cochrane Review concluded that modified D2 resections can be and currently are being performed with much lower operative morbidity and mortality [18].

\subsection{Adjunctive Therapies to Surgery}

Because of the poor outcomes of surgery for gastric cancer, there has been much interest in adjunctive therapies that, when used in addition to surgical removal of the primary tumor, may improve survival [19-22]. Adjuvant cytotoxic chemotherapy is successful in few gastrointestinal cancers [22] and many phase 3 clinical trials [19,20] have explored this approach in gastric cancer. However, the survival benefit gained from the use of adjuvant chemotherapy in gastric adenocarcinoma seems to be not clinically significant $[19,20]$ and for this reason adjuvant chemotherapy has not become part of the standard of care in gastric cancer.

Adjuvant chemotherapy rationale is a high risk of peritoneal and/or haepatic recurrence of gastric cancer. Drugs usually employed are 5-Fluorouracil (5-FU), Mitomycin-C, Cisplatin, Adriamycin, and Methyl-CCNU. Many authors report poor results in survival rate and, contrary to oldest trials, a recent prospective controlled 
study [23] did not demonstrate any improvement in survival by the administration after surgery of an association of 5-FU + cisplatin versus no treatment.

Intra-peritoneal chemotherapy is an alternative to the systemic way, essentially in prevention of peritoneal diffusion and seeding. Until now there were 5 controlled trials [24-28] about intra-peritoneal chemotherapy. In stage III cancer patients there was a significant difference in 5-year survival rate between those treated with early post-operative intra-peritoneal chemotherapy and those who underwent surgery alone [28]. This technique has high morbidity and mortality, it could be interesting in prevention of carcinomatosis but in selected patients.

The efficacy of radiotherapy has not been demonstrated in gastric cancer patients. Most of the trials associate radiotherapy and chemotherapy.

Other than these classical non-surgical interventions, immunotherapy is a well demonstrated approach for few cancers and may also be a potentially promising alternative strategy for gastric cancer. The benefit of immunotherapy is the specificity. It distinguishes the biological differences between normal and malignant cells to exert tumor cell death in a precise manner.

\section{Review Immunotherapy and Gastric Cancer}

\subsection{Tumor Immunology and Tumor Escape}

There is evidence that cancer to grow has to deal with immune system. This evidence has been demonstrated scientifically since early' 90 , when tumor antigens were identified and characterized and noted to be recognized by cytotoxic $T$ cells [29]. These proteins, produced by mutated DNA segments, are potentially immunogenic and could be recognized by immune system as antigens to reject. Immune responses against tumor antigens reflect immune responses against normal "self" tissue antigens, with some important and significant features that distinguish the tumoral pattern from the normal one. Tumors differ fundamentally from their normal cell counterparts in antigenic composition and biologic behaviour [30]. The molecular hallmark of carcinogenesis is a genetic instability [31]. This means that new antigens are constantly generated in tumors as they develop and progress. The normal antigens pattern instead maintains a stable profile. During tumorigenesis, hundreds of genes that are usually inactive in the normal tissue or expressed at relatively low levels are dramatically activated, raising the concentration of encoded proteins and affecting antigenicity [30].

Another important characteristic that qualify the malignancy of each tumor and directly affect morbidity and mortality is the ability of transformed malignant cells to invade across natural tissue barriers and to metastasize.
Both these features are never seen in normal tissues or benign tumors and they are associated with disruption of tissue architecture. At a biological level the most important consequence of tissue disruption, even when caused by non-infectious mechanisms, is the elaboration of pro-inflammatory signals [30]. These signals, generally in the form of cytokines and chemokines, are central initiators of both innate and adaptive immune responses.

These two characteristics: the ability to produce antigens and to elicit a pro-inflammatory cascade, demonstrate cancers' immunogenicity. The consequence of these findings is that tumor, to grow, needs to inhibit host's effective immune response.

In the past years many were the attempt to identify and characterize the mechanisms of tumor growth against host's immune system. One of the initial theory about it, which was firstly rejected but now reconsidered, is called: "immunological surveillance" $[32,33]$. This hypothesis consists in the fact that tumors can arise with the same frequency of infections caused by pathogens, and that immune system constantly suppresses them, recognizing tumor associated antigens. Those tumors clinically progressing are not eliminated by immune system because they are able to develop mechanism of immune escape or resistance.

In the past decades many attempts have been made to identified and characterized possible mechanisms used by tumors to escape immune surveillance $[34,35]$ and these can be summarized in the down regulation of MHC class I pathway, the lack of co-stimulatory function, the natural selection of poorly immunogenic tumor cells, the loss of tumor antigens, the defective "death receptors" signal, the suppression of immune response by tumor produced cytokines, the apoptosis of activated $\mathrm{T}$ cells and, recently introduced, the regulatory function of $\mathrm{CD} 4{ }^{+} \mathrm{CD} 25^{+} \mathrm{T}$ cells (regulatory $\mathrm{T}$ cells). No one of these mechanisms could explain alone tumor's growth in an immunocompetent host.

- The down regulation of the antigen processing MHC class I pathway has been documented in a large variety of human tumors, particularly breast cancer, prostate cancer and lung cancer [36-52]. Down regulating MHC class I pathway, antigens presenting cells are not able to process tumoral antigens and present them to $\mathrm{T}$ lymphocytes, leading to an ineffective cellular mediated immune response.

- To build an effective immune response, the immune system needs the presence of co-stimulatory molecules (e.g.: B7-1, B7-2). Lack of expression of these molecules by tumor cells will not lead to dendritic cells activation and maturation after recognition of tumor antigens, leading to $T$ cell anergy [53]. In an experimental setting, insertion of genes encoding B7-1, B7-2 or both into tumors generally increases 
the immunogenicity of those tumors but does not necessarily lead to cancer regression [54].

- Genomic instability, the main property of all tumors gives rise to genetic diversity [35]. The survival of cancer cells depends on natural selection, a passive process by which an organism has a survival advantage simply by possessing certain specific genes. Genomic instability creates a vast repertoire of tumor cells that will be selected according to environmental factors.

- The exact mechanisms that control the down-regulation of tumor antigens may be facilitated by "epitope immunodominance" [55]. The "immunodominance" consist in a preferential immunodetection of one or a few epitopes among many expressed on a given target. The parental tumor cells that carry the immunodominant epitope lead to a confined immune response, diverting attention from the tumor variants. Once the parental cells are eliminated, a new hierarchy is established among the variant subpopulations, and formerly immunorecessive epitopes become dominant [55].

- Two death receptor ligands that play a role in immune surveillance against tumor development are Fas ligand (FasL) and TRAIL [56-59]. These molecules transmit an apoptotic signal via the caspase cascade, through cytoplasmic sequences called "death domains". Loss of the gene encoding Fas has been identified in multiple myeloma [60], non-Hodgkin's lymphoma [61] and melanoma [62]. In addition, mutations of the genes in the proximal pathways downstream of Fas signaling have been also found in NSCLC and lymphoma [63,64].

- Activation or inhibition of T cells also depends on the presence or absence of cytokines in their immediate microenvironment. Tumor cells produce a variety of cytokines and chemokines that can suppress immune cells' function. Vascular endothelial growth factor (VEGF) is a cytokine secreted by most tumors [65] and in vitro studies show it inhibits dendritic cells differentiation and maturation [66]. In patients with gastric [67], lung, head and neck, and breast cancers [68], it has been noted a decrease in the function and number of mature dendritic cells, associated with increased plasma concentrations of VEGF. This fact was associated with a poor prognosis in gastric cancer patients. Also Interleukin-10 (IL-10) is a cytokine frequently detected in the serum of patients with cancer. IL-10 has an inhibitory effect on dendritic cells differentiation, maturation [69], antigen presentation, Interleukin 12 (IL-12) production and induction of T helper type 1 (Th1) responses in vivo [70,71]. It also enhances spontaneous dendritic cells apoptosis [72], and protects tumor cells from cytotoxic $\mathrm{T}$ cells func- tion by down-regulation of HLA classes I and II and ICAM-1 (intercellular adhesion molecule 1) [73].

- Recently, a subpopulation of thymus-derived $\mathrm{CD} 4^{+} \mathrm{T}$ cells, displaying high levels of $\mathrm{CD} 25$, has been described to suppress the function of self-reactive $T$ cells in the periphery [74-76]. These so-called regulatory $\mathrm{T}$ cells express all three subunits of the IL-2R but do not secrete IL-2 and, therefore, depend on exogenous IL-2 for survival and function. This has been demonstrated through in vitro mixed culture assays in which $\mathrm{CD} 4^{+} \mathrm{CD} 25^{+}$regulatory $\mathrm{T}$ cells mediate suppression of $\mathrm{CD}^{+} \mathrm{CD} 25^{-}$cells only in the presence of IL-2 [77]. Furthermore, IL-2 knockout mice, characterized as having significant impairment in regulatory $\mathrm{T}$ cells, develop severe autoimmunity that can be reversed by reconstitution of that pattern of cells from normal mice. The possibility that $\mathrm{CD} 4^{+} \mathrm{CD} 25^{+}$cells may influence patients with cancer has been suggested by the increased numbers of regulatory $\mathrm{T}$ cells demonstrated in a variety of human cancers, such as pancreas and breast adenocarcinoma, lung, gastric, esophageal, hepatocellular, ovarian cancer, melanoma and renal cell cercinoma [78-84].

\subsection{Immunity and Surgery}

Surgery is still the major prognostic factor for many solid cancers, such as the gastric one. There is evidence that surgical operations can cause a variety of immunological disturbances in man both in vivo and in vitro [85]. During the early postoperative course this may define a state of impaired defence and increased susceptibility to infection, septic complications and metastatic diffusion [8688], in particular in patients with politraumatic event, burn injury and cancer. During the past decade, experimental and clinical research has focused on the understanding of the pathophysiology of this immuno-inflammatory dysfunction.

Primarily, surgical trauma induces an acute phase response, which is capable of controlling tissue damage, killing infective organisms, and inducing repair processes in order to restore normal host function [88-90]. The acute phase response is initiated locally at the site of the surgical trauma by macrophages and monocytes, which release pro-inflammatory cytokines, in particular tumour necrosis factor alpha (TNF- $\alpha$ ) and interleukin-1 (IL-1) [91]. Studies refer that excessive release of TNF- $\alpha$ and IL-1, lead to increased mortality and an increased risk of postoperatory development of adult respiratory distress syndrome (ARDS) and multiple organ failure (MOF) [92]. TNF- $\alpha$ and IL-1 stimulate the production of other cytokines, such as interleukin-6 (IL-6), which peaks at 4 - 48 hours after surgery [93-94]. The release of IL-6 seems also to depend on the extent of tissue trauma [95]. In fact several studies demonstrates that there is a greater 
degree of IL-6 elevation after abdominal aortic and colorectal surgery than after hip replacement [95] and that there are lower IL-6 levels after laparoscopic procedures than after open operating procedures, including cholecystectomy and small bowel and colonic resections [96-100]. IL-6 stimulates neutrophils to produce acute phase proteins, such as C-reactive peptide, alpha-2 macroglobulin, which are involved in non-specific and specific immunity as inflammatory mediators, scavengers and protease inhibitors [91]. Other than this, IL-6 plays a major role in the proliferation of PMN progenitors in the bone marrow, and mechanical trauma has been shown to induce an early increase in circulating imamture PMNs [101]. After open cholecystectomy, which is associated with higher IL-6 levels, PMN superoxide anion release and chemotaxis are increased, in comparison with the less traumatic laparoscopic approach [102]. IL-6 is also an important immunoregulatory cytokine [103]. IL-6triggered acute phase response, in fact, induces macrophages to release prostaglandin E2 (PGE2) [90], which is probably the most powerful endogenous immune suppressant. PGE2 inhibits T-cell mitogenesis, interleukin-2 (IL-2) production, and IL-2 receptor (IL-2r) expression [104]. Stimulating interleukin-4 (IL-4) action, PGE2 also induces the release of IL-10 [105]. IL-6 is capable of downregulating pro-inflammatory cytokines and, additionally, of exerting profound anti-inflammatory actions, resulting in a dramatic cytokine misbalance, which is clinically reflected by a compensatory anti-inflammatory response syndrome [106]. Thus, as a final effect, surgical trauma-induced immunosuppression, which is characterized by low levels of pro-inflammatory TNF- $\alpha$, IL- 1 , IL-12, and interferon gamma (IFN- $\gamma$ ) but markedly elevated levels of anti-inflammatory IL-6, IL-10, and IL-1 $[103,106,107]$. These results are further confirmed by studies that demonstrate that a reduction of surgical trauma by the use of a minimally invasive laparoscopic approach significantly reduces the increased serum levels of IL- 6 and IL-10, and restores the decreased IFN- $\gamma$, TNF- $\alpha$, and IL- 2 production by T cells $[100,108]$.

Moreover, cell-mediated immunity is based on an effective interaction between macrophages and T cells. During trauma or sepsis, macrophages and monocytes are triggered to produce and release PGE2, which initiates a sequence of events, resulting in T cells inhibition [109]. The process result also in a deactivation of monocytes, which is characterized by a reduced human leukocyte antigen (HLA-DR) receptor expression, a loss of antigen-presenting capacity, and a pronounced reduction in their ability to produce TNF- $\alpha$ [110]. This monocytic deactivation involves IL-10, because a neutralizing antibody against IL-10 has been shown to restore significantly the LPS-induced pro-inflammatory cytokine production [111]. Apart from IL-10, the anti-inflammatory transforming growth factor beta (TGF- $\beta$ ) may additionally contribute to the surgical trauma-induced monocyte deactivation. Haemorrhage, and also major surgical trauma, such as thoraco-abdominal aortic aneurysm repair, induces a significant increase in circulating TGF- $\beta[112$, 113], which is associated with a marked depression of macrophage antigen presentation [112].

The innate cellular immune system seems to be inactivated by surgical trauma too. In fact, major surgical interventions are associated with a significant decrease in total systemic lymphocyte counts, including both $\mathrm{CD}^{+}$ and $\mathrm{CD}^{+}$cells [114]. This lymphocyte depression has been shown to correlate with the duration of the surgical procedure, and the volume of blood loss, however, was not associated with the extension of the trauma, the age of the patient, or the type of intensive care intervention [114]. The cause of the fall in lymphocyte count due to surgical trauma may involve a dysregulated expression of apoptotic death and survival factors. A study demonstrated an increase $\mathrm{CD}^{+}$and $\mathrm{CD} 8^{+} \mathrm{T}$ cells' apoptosis 24 hours after surgery than before the intervention, associated with a downregulation of anti-apoptotic factors such as $\mathrm{Bcl}-2$ [115]. The impact of this immune dysfunction was underlined by the result that the rate of apoptotic $\mathrm{CD} 8^{+}$cells significantly correlated with the manifestation of infectious complications during the postoperative course [115]. Also this post-surgery increase of apoptotic $\mathrm{CD}^{+}$and $\mathrm{CD} 8^{+} \mathrm{T}$ cells' death is associated with the elevated levels of IL-10 [116].

Other studies demonstrated that modulation of T-helper lymphocytes is also involved in the development of immunosuppression after surgical trauma. Th cells can be subdivided into two functionally distinct subsets: Th1 and Th2 cells. Th1 cells may support an inflammatory response by producing IL-2, IL-12, and INF- $\gamma$, while Th2 cells act as anti-inflammatory agents by secreting IL-4, IL-5, IL-6, IL-10, and IL-13. After major surgery the cytokine secretion of $\mathrm{T}$ cells obtained from peripheral blood mononuclear cells (PBMCs), stimulated by crosslinking of $\mathrm{CD} 3$ and $\mathrm{CD} 28$, was reduced for IL-2, IFN- $\gamma$, and TNF- $\alpha$, which are associated with the Th1 phenotype [89]. In contrast, the anti-inflammatory cytokine IL-10 was selectively elevated during the late postoperative course, indicating a shift of the Th1/Th2 balance towards a Th2 response [89]. That this deregulation of $\mathrm{T}$ lymphocyte function is induced by surgical trauma is confirmed by the results of another study, which demonstrates that minimization of the trauma by laparoscopic surgery results in restoration of an adequate Th1/Th2 and pro-inflammatory/anti-inflammatory cytokine balance [108].

\subsection{Cancer Immunotherapy}

One immediate goal of research in cancer immunology is 
the development of methods to enhance a host's effective immune response against tumor. Many are the treatments based on a restoration of immune system. We call active immunization the attempt to train the patient's immune system to recognize tumor cells as targets to be destroyed. This could be obtained by the administration of tumoral antigens presented by dendritic cells, the so called "anti-tumor vaccine", or by autologous tumoral cells genetically modified in production cytokines. Another way to immunizate cancer patients is through the administration of therapeutic antibodies or cytokines, in which case the patient's immune system is recruited to destroy tumor cells by the therapeutic antibodies and cytokines (passive immunization).

Antibodies are a key component of the adaptive immune response, playing a central role in both in the recognition of foreign antigens and the stimulation of an immune response. The advent of monoclonal antibody technology has made it possible to raise antibodies against specific antigens such as the unusual antigens that are presented on the surfaces of tumors. While antibodies targeted to disease-causing antigens can be effective under certain circumstances, in many cases, their efficacy may be limited by other factors. In the case of cancer tumors, the microenvironment is immunosuppressive, allowing even those tumors that present unusual antigens to survive and flourish in spite of the immune response generated by the cancer patient, against his or her own tumor tissue.

Cytokines, such as IL-2, also play a key role in modulating the immune response, and have been tried in conjunction with antibodies in order to generate an even more devastating immune response against the tumor.

Vaccination can stimulate humoral, cellular and innate immune systems to generate various effector molecules, like antibody, cytotoxic T cells, cytokines etc. This is an antigen specific immunotherapy, in which the immune system can be stimulated actively by antigen based tumor vaccine to kill only those tumor cells, having expression of the particular tumor associated antigen.

\subsection{Gastric Cancer Immunotherapy}

Immunotherapy may be a potentially promising alternative strategy for gastric cancer. In early clinical trials, systemic immunotherapy included both active vaccination directed against defined tumor-associated antigens expressed in gastric carcinoma cells [117] and passive administration of IL-2 with some evidence of regression of metastatic gastric cancer $[118,119]$. Other studies have applied immunotherapy in the adjuvant setting with equally promising results. Adjuvant immunotherapy is expected to exert a synergistic effect with surgical resection. For example: OK-432, a streptococcal preparation, which is one of the most commonly used non-specific enhancer of immune system, demonstrated marginal improvement in survival for patients with stage III gastric cancer [120]. Administration of OK-432 has been reported to induce the release of various cytokines, such as TNF- $\alpha$, INF- $\beta$, IL- 8 , IL-12, etc., and has also been shown to enhance cytotoxicity against autologous cells. Furthermore it induces augmentation of perforine and the upregulation of FAS ligand, promoting anti-tumor necrotic and apoptotic effects by natural killer cells (NK) and lymphocytes activated killers (LAK). OK-432 has been initially administered in a neoadjuvant setting with preoperative endoscopical intratumoral injection to stimulate an increase of tumor infiltrating lymphocytes (TILs), which are a well-known prognostic factor in gastric cancer patients [121]. In OK-432 treated patients, TILs were moderately present in $40 \%$ and markedly present in $33 \%$ of cases, compared to $31 \%$ and $0 \%$ of cases respectively in the control group. A recent study demonstrate that OK-432 significantly increase the 5- and 10year survival rates of patients with stage IIIA + IIIB gastric adenocarcinoma [120]. OK-432 was most effective in prolonging survival of patients who had both positive TILs and lymph node metastases. In fact, in TILs positive patients a significant decrease in metastatic lymph node frequency and in the number of lymph node micrometastatic foci was noted. It probably acts partly by eliminating micro-metastatic foci in lymph nodes. Different studies employed adjuvant OK-432 in a subcutaneous route of administration. In a recent study it has been showed a difference in overall survival between OK-432 and control groups, with a reduction of $13 \%$ in the 3-year death rate $[121,122]$. A meta-analysis of centrally randomized controlled clinical trials indicated a significant survival benefit with combination of OK-432 and chemotherapy compared to chemotherapy alone ( $p<$ 0.05 ) as shown in Table 1 [123]. PSK (polysaccaride K) seems to achieve comparable results in an adjiuvant setting. Because of OK-432 and PSK have similar immunomodulatory effects, but are not necessarily effective as monotherapy against gastric cancer, the benefits of immuno-chemo-therapy after curative resection of gastric cancer may be caused by the restoration of immunity in patients who have immunosuppression because of surgery and subsequent chemotherapy. Recent advances in molecular biology suggest that immunomodulation by OK-432 may sensitize peripheral blood lymphocytes (PBL) to OK-432, leading to the subsequent activation and proliferation of cytotoxic effect cells.

Recent studies on gastric cancer demonstrated that gastrin-17 (G17), the predominant form of circulating gastrine hormone, is a tumor growth factor, with proangiogenic and antiapoptotic effects (Figure 1), and gastric cancer cells overexpress gastrin genes. G17DT is a therapeutic immunogen which elicit specific and high-affinity antigastrin antibodies to bind G17, thus preventing 
Table 1. A meta-analysis of centrally randomized controlled clinical trials.

\begin{tabular}{|c|c|c|c|c|c|c|c|c|c|c|}
\hline No. & Study & Interventions & Participants No. & $\begin{array}{c}\text { Excluded } \\
\text { population } \\
(\%) \\
\end{array}$ & $\begin{array}{l}\text { Analyzed } \\
\text { cases }\end{array}$ & $\begin{array}{c}\text { Male } \\
(\%)\end{array}$ & $\begin{array}{l}\text { Stage III } \\
\text { over }(\%)\end{array}$ & $\begin{array}{l}\text { Five year } \\
\text { survival rate } \\
(\%) \text { death }\end{array}$ & Death & $p$-value \\
\hline \multirow[t]{2}{*}{1} & \multirow[t]{2}{*}{$\begin{array}{l}\text { Niimoto et al. } \\
\text { (SA G-Kyushu) }\end{array}$} & $\begin{array}{l}\text { A: Mitomycin C(MMC) } 20 \mathrm{mg} \text { i.v } \\
\text { day } 1 \text {, futraful (FT) } 00 \mathrm{mg} / \text { day orally } \\
\text { for } 1 \text { year B: MMC } 20 \mathrm{mg} \text { i.v day } 1 \text {, } \\
\text { PSK } 3 \mathrm{~g} / \text { day and FT } 600 \mathrm{mg} / \text { day } \\
\text { orally for } 1 \text { year }\end{array}$ & 256 & 22.0 & 199 & & & 58.5 & 83 & 0.004 \\
\hline & & $\begin{array}{c}\text { B: MMC } 20 \mathrm{mg} \text { i.v day 1, PSK } 3 \\
\text { g/day and FT } 600 \mathrm{mg} / \text { day orally for } 1 \\
\text { year }\end{array}$ & 264 & 28 & 191 & & & 71.7 & 54 & $\cdots$ \\
\hline \multirow[b]{2}{*}{2} & \multirow[b]{2}{*}{$\begin{array}{l}\text { Kondo et al. } \\
\text { (SACG-Chubu) }\end{array}$} & $\begin{array}{l}\text { A: FT } 600-800 \mathrm{mg} / \text { day orally for } 3 \\
\text { months with } 2 \text { months rest }\end{array}$ & 208 & 23.6 & 159 & & & 63.6 & 58 & 0.135 \\
\hline & & $\begin{array}{c}\text { B: FT } 600-800 \mathrm{mg} / \text { day orally for } 3 \\
\text { months and PSK } 3 \text { g/day during } 2 \\
\text { months rest }\end{array}$ & 198 & 26.8 & 145 & & & 71.3 & 42 & $\cdots$ \\
\hline \multirow[b]{2}{*}{3} & \multirow{2}{*}{$\begin{array}{l}\text { Kondo et al. } \\
\quad \text { (TGOG) }\end{array}$} & $\begin{array}{l}\text { A: Carbazilquinone (CQ) } 2 \mathrm{mg} / \mathrm{m}^{2} \\
\text { I.V on day } 0,815 \text { in each course }\end{array}$ & 75 & 34.7 & 49 & 59.2 & 40.7 & 47.1 & 27 & 0.690 \\
\hline & & $\begin{array}{l}\text { B: CQ } 2 \mathrm{mg} / \mathrm{m}^{2} \text { i.v on day } 0,8,15 \\
\text { amd PSK } 2 \mathrm{mg} / \mathrm{m}^{2} \text { orally from day } 15 \\
\text { for } 4 \text { weeks }\end{array}$ & 65 & 27.7 & 47 & 63.2 & 65.3 & 45.3 & 27 & $\cdots$ \\
\hline \multirow{2}{*}{4} & \multirow{2}{*}{$\begin{array}{l}\text { Ogawa et al. } \\
\text { (KGSG) }\end{array}$} & $\begin{array}{c}\text { A: MMC } 0.4 \mathrm{mg} / \mathrm{kg} \text { i.v day } 0 \text { and } \\
0.2 \mathrm{mg} / \mathrm{kg} \text { day } 1, \mathrm{HCFU} 400 \mathrm{mg} / \text { day } \\
\text { orally for } 1 \text { year }\end{array}$ & 69 & 20.2 & 55 & & 21.0 & 81.1 & 9 & 0.810 \\
\hline & & $\begin{array}{l}\mathrm{B}: \mathrm{MMC} 0.4 \mathrm{mg} / \mathrm{kg} \text { iv day } 0 \text { and } 0.2 \\
\mathrm{mg} / \mathrm{kg} \text { day } 1, \mathrm{HCFU} 400 \mathrm{mg} / \text { day and } \\
\text { PSK } 3 \mathrm{~g} \text { /day orally for } 1 \text { year }\end{array}$ & 70 & 20.0 & 56 & & 41.0 & 80.2 & 11 & $\cdots$ \\
\hline \multirow[t]{4}{*}{5} & \multirow{4}{*}{$\begin{array}{l}\text { Nakazato et al. } \\
\text { (SIP) }\end{array}$} & $\begin{array}{l}\text { A: MMC } 6 \mathrm{mg} / \mathrm{m}^{2} \text { i.v day } 0 \text { and } 1 \text {, } \\
\text { fluorouracil }(\mathrm{FU}) 150 \mathrm{mg} / \text { day orally } \\
\text { for } 4 \text { weeks with } 4 \text { weeks rest } \\
\text { B: MMC } 6 \mathrm{mg} / \mathrm{m}^{2} \text { i.v day } 0 \text { and }\end{array}$ & 129 & 0.0 & 129 & 66.7 & 65.1 & 60.0 & 52 & 0.044 \\
\hline & & & 124 & 0.0 & 124 & 66.9 & 64.5 & 73.0 & 33 & $\ldots$ \\
\hline & & $\begin{array}{c}\text { A: MMC } 20 \mathrm{mg} \text { bolus day } 0 \text { and } 1 \text {, } \\
\text { tegafur } 600 \mathrm{mg} / \text { day orally for } 8 \\
\text { months }\end{array}$ & 1.897 & 20.1 & 1.509 & 63.9 & 65.8 & 60.2 & 620 & 0.500 \\
\hline & & $\begin{array}{l}\text { B: MMC } 20 \mathrm{mg} \text { bolus day } 0 \text { and } 1 \text {, } \\
\text { tegafur } 600 \mathrm{mg} / \text { day orally and PSK } 3 \\
\mathrm{~g} / \text { day for } 8 \text { months }\end{array}$ & 1.942 & 16.7 & 1.601 & 61.8 & 66.8 & 61.2 & 638 & $\ldots$ \\
\hline \multirow[t]{2}{*}{6} & JFMTC-1 & $\begin{array}{l}\text { C: MMC } 20 \mathrm{mg} \text { bolus day } 0 \text { and } 1 \text {, } \\
\text { tegafur } 600 \mathrm{mg} \text { /day orally and OK } \\
432 \text { totally } 100 \mathrm{KE} \text { for } 8 \text { months }\end{array}$ & 1.907 & 18.5 & 1.543 & 63.8 & 69.1 & 58.7 & 660 & $\ldots$ \\
\hline & & $\begin{array}{c}\text { D: MMC } 20 \mathrm{mg} \text { bolus day } 0 \text { and } 1 \text {, } \\
\text { tegafur } 600 \mathrm{mg} / \text { day orally, OK } 432 \\
\text { totally } 100 \mathrm{KE} \text { and PSK } 3 \mathrm{~g} / \text { day for } 8 \\
\text { months }\end{array}$ & 1.891 & 17.8 & 1.544 & 65.7 & 68.5 & 60.2 & 633 & $\cdots$ \\
\hline \multirow[b]{2}{*}{7} & \multirow[b]{2}{*}{ JFMTC-5 } & A: Tegafur $600 \mathrm{mg} /$ day orally & 222 & 2.3 & 217 & 65.9 & 53.0 & 47.0 & 115 & 0.350 \\
\hline & & $\begin{array}{c}\text { B: Tegafur } 600 \mathrm{mg} / \text { day orally } \\
\text { and PSK } 3 \mathrm{~g} / \text { day }\end{array}$ & 220 & 2.5 & 215 & 60.7 & 51.2 & 52.8 & 101 & $\cdots$ \\
\hline \multirow{2}{*}{8} & \multirow{2}{*}{ JFMTC-11 } & A: Surgery alone & 114 & 1.8 & 112 & 65.8 & 8.7 & 83.3 & 20 & 0.769 \\
\hline & & B: PSK $3 \mathrm{~g}$ /day orally for 6 months & 114 & 0.0 & 114 & 67.0 & 5.4 & 84.8 & 19 & $\ldots$ \\
\hline
\end{tabular}

SACG: The Co-Operative Study Group of Surgical Adjuvant Chemotherapy for Gastric Cancer; TGOG: Tokai Gastrointestinal Oncology Group; KGSG: Kunamoto Gastrointestinal Immunochemotherapy Study Group; SIP: The Study of Immunochemotherapy with PSK for Gastric Cancer; $95 \%$ CI: 95\% Confidence Interval.

its trophic activity. Intramuscular vaccination with G17DT seems to prolong overall survival in certain patients affected by advanced gastric cancer [124].

Another way to utilize immunotherapy in gastric cancer patients as been analized by Kono et al. [125]. They reported that CTLs from gastric cancer patients, which are restricted to MHC class I, can react specifically against autologous tumor cells. Therefore, adoptive immunotherapy with tumor-associated lymphocytes (TALs) can have therapeutic activity and can induce regression of established tumors or micrometastases in adjuvant setting associated with chemotherapy. In advanced gastric cancer patients they reported an overall survival rate significantly better than in control group $(p<0.05)$, and 


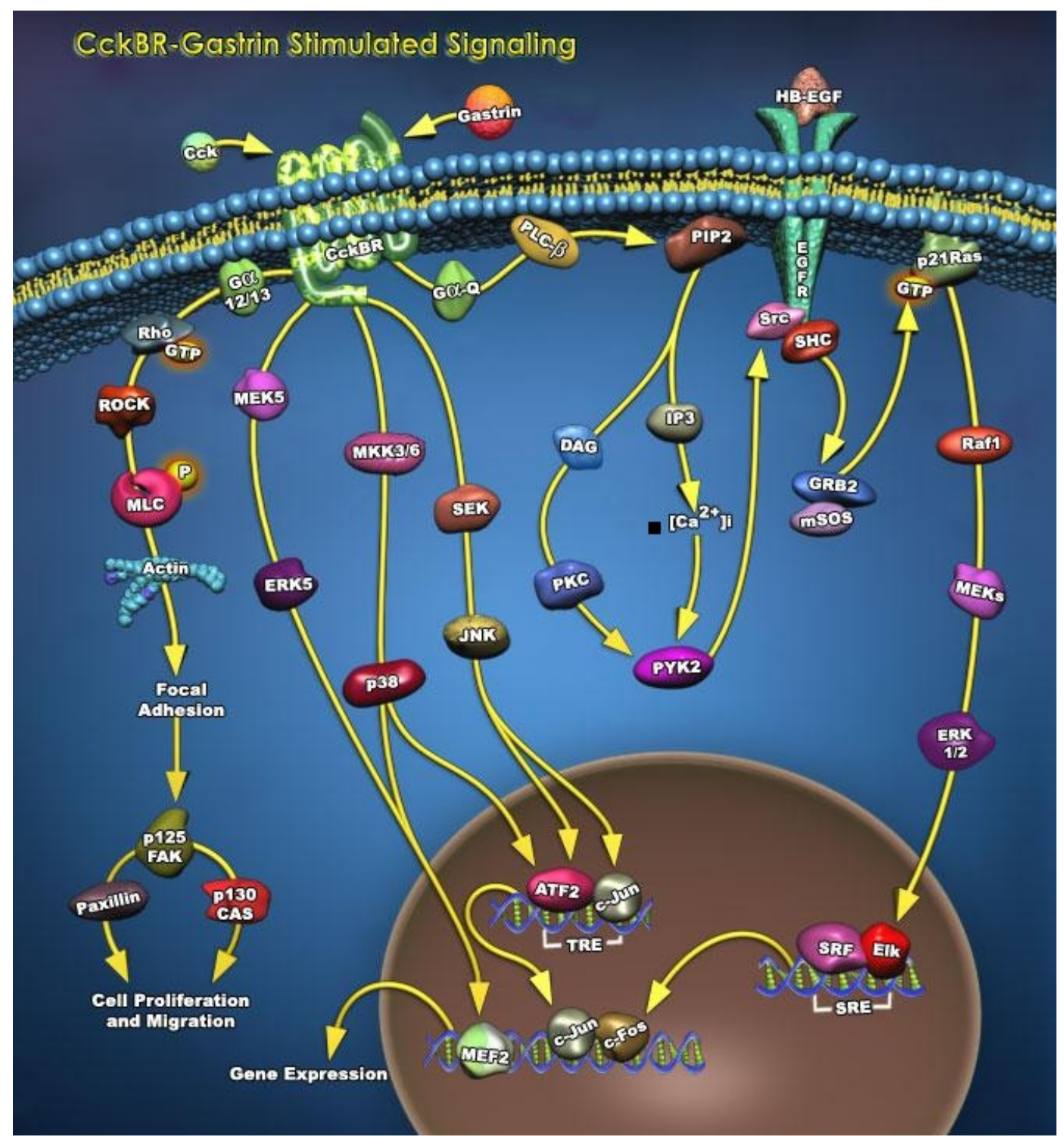

Figure 1. This chart illustrates gastrin pathway: signaling pathways associated with the gastrin-releasing peptide receptor (GRPR) in cancer. Gray lines indicate possible functional interactions. Black lines indicate established pathways activated upon GRPR stimulation.

adoptive immunotherapy is an indipendent prognostic factor for these patients, indicating that it influenced patient survival in a positive manner.

In a recent study Wu et al. [126] utilized Dendritic cells (DC) as a vector for immunotherapy in gastric cancer patients. DC are the professional antigen-presenting cells (APCs) specialized to initiate and regulate immune response. DC loaded with tumor antigens is able to induce protective antitumor responses and produce significant therapeutic immunity to established tumor. DC during their maturation develop the ability of antigen uptake and capture and of presenting antigen and release IL-12, that enhance both innate (NK cells) and acquired (B and $\mathrm{T}$ cells) immunity. The use of DCs pulsed with tumor peptide or loaded with tumor cells lysate create vaccines which works against tumor and has been used in advanced gastric cancer patients. Gastric cancer seems to overexpress HER-2/neu and vaccination with DCs pulsed with HER-2/neu peptide intradermally results in tumor regression and decrease of tumor markers (CEA or Ca19-9).

More than 15 years ago, gene therapy emerged as a new therapeutic approach and has meanwhile become an important strategy in cancer treatment. The original concept of cancer gene therapy was further developed into two branches as a result of different strategies of therapeutic benefit: molecular cancer therapy and virotherapy. Molecular cancer therapy can be defined as a therapeutic 
technique, which aims at the introduction of nucleic acids into cancer patients' cells in order to modulate the gene expression profile of the target cells and thereby eradicate the tumor. In contrast, virotherapy is a new concept of gene therapy that uses replication-competent oncolytic viral vectors (OVV) with viro-oncolytic potency for targeted tumor cells destruction. There are different ways to modulate tumor growth by gene therapeutic strategies. These include direct destruction of tumor cells, inhibition of tumor angiogenesis and tumor cell spread and activation of the host immune response against the tumor. The benefit of using cytokines can be improved if combined with other gene therapeutic options. For examples, synergistic anti-tumor effect was achieved by simultaneous expression of IL- 2 and IFN- $\beta$, or by combining an oncolytic adenovirus (oAdV) with IL-12 immunotherapy. Zhang et al. evaluated the anti-tumor effects of the HSVtk/GCV system (a suicide gene system: herpes simplex virus thymidilate kinase ganciclovir) together with the expression of recombinant IL-2 or TNF- $\alpha$ in gastric cancer [127]. Using similar protocols others groups found strongly enhanced anti-tumor effects after coexpression of IL-2, GM-CSF and HSV-tk/GCV in a gastric cancer model [128]. These results strongly indicate the potential impact of combined cytotoxic and immunomodulatory gene therapy in gastric cancer patients.

Other attempts were made in enhancing host's immune system against gastric cancer. We recently published the definitive results, with the full accrual of patients and a median follow-up of 51 months, of a randomized trial in which we evaluated the clinical benefit of patients treated with Interleukin-2 before undergoing surgery. There are data suggesting a biological and clinical benefit of subcutaneous, preoperative administration of low-dose IL-2 in colon cancer [129-131], which encouraged us to evaluate low-dose IL-2 therapy in the neoadjuvant setting for patients with gastric adenocarcinoma who underwent surgery and to evaluate its effects on systemic and tumor infiltrating lymphocyte numbers. We also sought to determine if neoadjuvant low-dose IL-2 could influence the clinical outcome for patients undergoing gastric resection for cancer.

IL-2 was first described as a $\mathrm{T}$ cell growth factor $[132,133]$. It is produced by activated $\mathrm{T}$ cells and stimulates the growth and function of T cells and NK cells. A decreased endogenous IL-2 production is known to occur in cancer patients with advanced stages, possible due to tumor-released factors such as IL-10, TGF- $\beta$ and sIL-2r, and inducing a cell-mediated immunodeficiency status, which is demonstrated to be clinically relevant. In fact, either the total and the T-cell lymphocytopenia represents a prognostic factor for a poor survival in cancer patients, independent by other well known clinical prognostic factors such as performance status, disease extent, and weight loss. Moreover, although radical surgery represents the only curative treatment, the biological response to major surgical trauma induces a temporary immunosuppression, likely due to the release of polipeptidic mediators having immunosuppressive activity and to the direct inhibition of circulating lymphocytes by monocytes/macrophages induced by laparotomic surgical stress. The postoperative period likely represents a critical time for the subsequent evolution of the disease, during which an effective cell-mediated immune response may eliminate the minimal neoplastic residual after macroscopic radically surgery; on the contrary an impaired immune surveillance can allow the growth of the few residual cancer cells, spread before and/or during surgery. In fact, in colorectal cancer patients, the lack of recovery of circulating T-cells in the late postoperative period is associated with a worse prognosis. The active managing of the immune response in the postoperative period may represent a powerful strategy for improving the therapeutic effectiveness of surgery: for this purpose, the administration of interleukin-2 the T-cell growth factor seems actually the most active cytokine, able to revert the cell-mediated immunodeficiency.

IL-2 was first used in patients with advanced cancer, and some clinical responses were seen [134], allowing FDA to licence IL-2 as a therapy in metastatic melanoma and metastatic renal cell carcinoma. However, extremely high doses were given in the initial cancer trials (up to 150 million units per day) resulting in severe toxicity, including capillary leak syndrome, hypotension and pulmonary edema. Many of the first patients treated on this high dose regimen required hospitalization in an intensive care unit. Because of its central role in $\mathrm{T}$ cell immunity, IL-2 was also one of the first immune-based therapies to be tested in patients with HIV. In these studies an intermediate dose was given. Kovacs et al. [135] administered 18 million units per day for 5 days every 8 weeks by continuous intravenous infusion in the hospital. The results were significant in patients with baseline CD4 counts $>200$ cells $/ \mathrm{mm}^{3}$. In addition, the infusion of IL-2 was still associated with side effects such as fever and flu-like symptoms. Subsequent trials of intermittent intermediate dose IL-2 have mainly used subcutaneous administration, since this seems to have similar efficacy with less severe side effects and allows outpatient administration [136]. In addition, some have argued for low dose, continuous IL-2 rather than intermittent IL-2 at higher doses [137]. In previous randomized studies on patients with advanced colorectal cancer undergoing surgery, the preoperative administration of IL-2 sc. for 3 days at a dose of 18 million UI/daily was active in the prevention of postoperative immunodepression and was effective in improving the overall survival in IL-2 treated patients vs control patients, with moderate toxicity. 
More recently, studies on human immunodeficiency virus (HIV) patients, demonstrated that IL-2 at 9 million UI/daily, administered subcutaneously for 5 days every 2 months, induce significant activation and growth of $\mathrm{T}$ helper lymphocytes in patients with HIV related immunodeficiency. Subcutaneous administration is less toxic and warrants a better distribution, in lymphatic compartment, where the interaction between IL-2 and cell receptors occurs, in comparison with the intravenous administration route. Preoperative IL-2 administration at 18 million IU/daily subcutaneously for 3 days induced a significant durable lymphocytes increase and improved the survival in a series of colorectal patients in previous study, but such a treatment had to be performed as inpatient therapy so increasing the treatment costs. Lower IL-2 dosing administered in a shorter period might make this treatment feasible as outpatient, and less expensive. Moreover it has been postulated on clinical grounds that the anticancer effects of IL-2 are mediated through in vivo expression and activation of cytotoxic lymphocytes and/or promotion of their migration within target tissues. It is well known that most solid human neoplasms are infiltrated by poly- and mononuclear cell infiltrate [138, 139]. This tumor infiltrating lymphocytes (TILs) has been recognized as a tumor-host reaction in various neoplasms $[140,141]$ and usually contains a predominantly $T$ lymphocytic infiltrate associated with the host's specific immune response to the neoplasm. The degree of infiltration has been suggested to be a measure of the host immune response. An increased TIL, with high number of activated cytotoxic lymphocyte, have been linked to prognosis in some tumors like colorectal carcinoma, medullary carcinoma of the breast and malignant melanoma with a clear positive correlation between the density of the lymphoid infiltrate at the advancing margin of the tumor and the prognosis of the patients.

\section{Discussion}

Our personal experience in gastric cancer immunotherapy.

In recent years many trials were conducted with different IL-2 regimens in solid tumors other than melanoma and renal cell carcinoma with variable results [142]. IL-2 was also used to improve the anti-tumor activity of other forms of immunotherapy [143-150] chemotherapy [151$156]$ and surgery [157-163].

Immunotherapy with IL-2 may thus also be a potentially promising alternative strategy for gastric cancer. We enrolled 68 patients with assessable gastric cancer, who met eligibility criteria for IL-2 administration and surgical procedures, between October 1999 and July 2003 [164]. Patients were randomized in two groups: one was treated before surgery with low doses IL-2 (cases), the other underwent surgery without having been treated (controls). Low dose IL-2 was administered subcutaneously at 9,000,000 UI twice a day for three days. Patients underwent gastric surgery 36 hours after the last dose. Other than characterize the peripheral blood count, such as Total peripheral WBC, neutrophils, total lymphocytes $\left(\mathrm{CD}^{+}\right)$, T helper lymphocytes $\left(\mathrm{CD} 4^{+}\right)$, cytotoxic lymphocytes $\left(\mathrm{CD}^{+}\right)$and Natural Killers (NKs), we also looked at the peritumoral infiltration and we graded its density according to the classification of Ropponen modified [165] and four grades were established, for both lymphocytic, eosinophylsic, and neutrophilic infiltration: negative ( $0: 0$ cells/field $)$, weak $\left({ }^{+}: 1-30\right.$ cells/field), moderate $\left({ }^{++}: 30-50\right.$ cells/field $)$, dense $\left({ }^{++}:>50\right.$ cells/field).

Patients' age, sex, site of tumor, type and grading of tumor, stage of tumor, type of surgical intervention and total months of follow up, were not significantly different in the two groups. Thirty patients $(44.1 \%$ of the total), fifteen cases and fifteen controls, underwent partial gastrectomy; thirty-eight (55.9\%), twenty-one cases and seventeen controls, underwent total gastrectomy. The surgical choice was determined by tumor site. Total gastrectomy was preferred to partial gastrectomy when the tumor was localized to the cardia.

Pre-operative administration of low-dose IL-2 resulted in very mild toxicity, which mostly consists in fever and common flu-like symptoms, skin erythema at the injection site which spontaneously disappeared in a few days.

Our data demonstrated a decrease in total peripheral blood lymphocytes below 1000 cells $/ \mathrm{mm}^{3}(805 \pm 446$ lymphocytes $\left./ \mathrm{mm}^{3}\right) 7$ days after surgery starting from a mean baseline value of $1172 \pm 4281$ ymphocytes $/ \mathrm{mm}^{3}$ for those patients who were not pre-treated with IL-2. We also observed a specific decrease in $\mathrm{CD}^{+} \mathrm{T}, \mathrm{CD} 8^{+} \mathrm{T}$ and NK cell counts after operation (Figure 2). This decrease after tumor manipulation during surgery might provide a fertile environment for residual tumor cells to grow or for micrometastasis to develop. It is not known if improvements in surgical technique and keeping tumor manipulation to a minimum during operation will prevent the decrease in lymphocyte depletion post-operatively. Seven days after operation we noted a minor decrease in peripheral blood $\mathrm{CD}^{+} \mathrm{T}$ cells, $\mathrm{CD} 4^{+} \mathrm{T}$ cells, $\mathrm{CD} 8^{+} \mathrm{T}$ cells and NK cells in patients pre-treated with low-dose IL-2 compared to control patients (Figure 2). This minor decrease was statistically significant for $\mathrm{CD}^{+}$and $\mathrm{CD} 4{ }^{+}$ $\mathrm{T}$ cells $(p<0.05)$. While we also observed a trend toward decreasing in $\mathrm{CD} 8^{+} \mathrm{T}$ cells and NKs in control patients, this did not reach statistical significance due to the high variability within the population. After 7 days, lymphocyte counts in IL-2-treated and control patients increased at a similar rate suggesting that the activity of IL-2 is most pronounced in the first week after surgery. In general, surgical trauma induces lymphopenia with a slow 

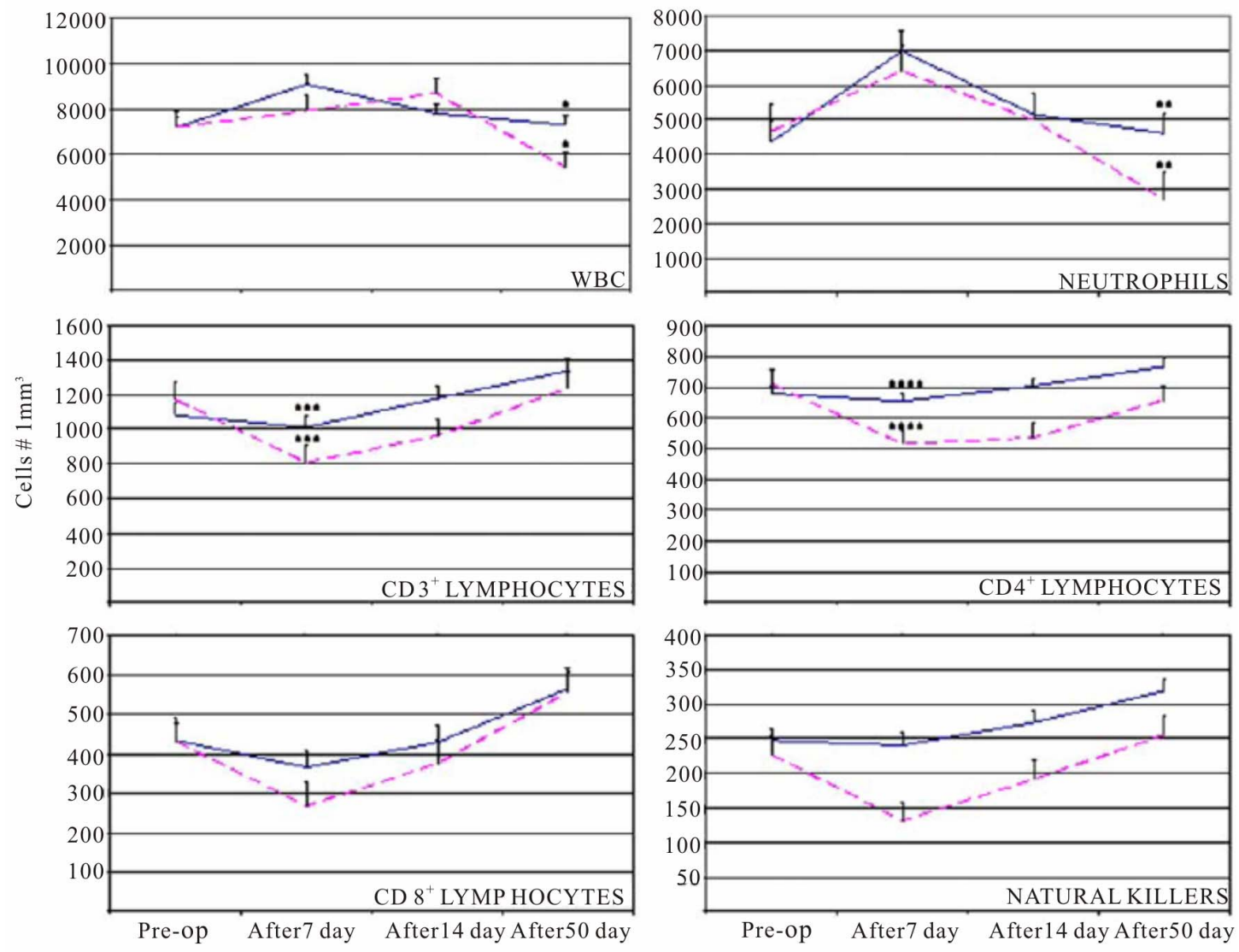

Times of drawing

Figure 2. Total WBC, neutrophils, $\mathrm{CD3}^{+} \mathrm{T}, \mathrm{CD}^{+} \mathrm{T}, \mathrm{CD8}^{+} \mathrm{T}$ and NK cells counts were assessed by flow cytometry on peripheral blood samples preoperatively (Pre-op) and on days 7, 14 and 50 after surgery. A significantly higher number $(p<0.05)$ of total WBC and neutrophils was noted in cases (continuous line) compared to controls (dashed line) on 50th day after surgery. Seven days after surgery, the decrease in $\mathrm{CD}^{+}$and $\mathrm{CD}^{+} \mathrm{T}$ cell number was significantly lower $(p<0.05)$ in cases than in controls.

rebound depending on the type and severity of trauma. IL-2 appears to set a higher starting point for the lymphocyte rebound after trauma. In addition to peripheral blood lymphocytes, we also analyzed the local peritumoral cellular infiltrates.

Our data suggested that there was an increase in lymphocytic and eosinophilic infiltration in patients pre-treated with IL-2 compared to controls (see Figure 3). These data imply that IL-2 might act to abolish the post-operative decrease in peripheral blood lymphocytes and also increase the local accumulation of lymphocytes and eosinophils within the tumor. This is consistent with data from melanoma patients where IL-2 has been shown to induce lymphocytic infiltration into tumors of patients who achieved clinical responses [166]. An increased in eosinophilic infiltrates have also been reported in patients with colon cancer pre-treated with IL-2 [167]. The activity of IL-2 on peritumoral lymphocytes and eosinophils is perhaps not unexpected and may result from direct action on the IL-2 receptor, which is expressed by both activated lymphocytes and eosinophils [168], and an indirect action due to an IL-2-mediated cascade of cytokines and chemokines that results in lymphocyte and eosinophil migration and proliferation. The presence of peritumoral infiltrating lymphocyte is a well described phenomenon in cancer patients and typically relates to a better prognosis as reported in patients with primary malignancies of the lung [169], liver [170], ovary [171], colon $[172,173]$, genitourinary tract [174] and stomach [175]. IL-2 seems not to modify the composition of lymphocytic infiltration, which resulted to be mostly made by $\mathrm{T}$ cells, widespread diffused into the tumor, and by $\mathrm{B}$ cells, peripherally organized in a nodular shape. Although the changes in lymphocyte frequency with neoadjuvant IL-2 were interesting, we did not notice an improvement in relapse-free or overall survival. Stepwise multivariate analyses were made to evaluate factors that influenced survival and found that tumor stage and patient age were the only predictors of response in our patients. It was not unexpected that a better prognosis was 


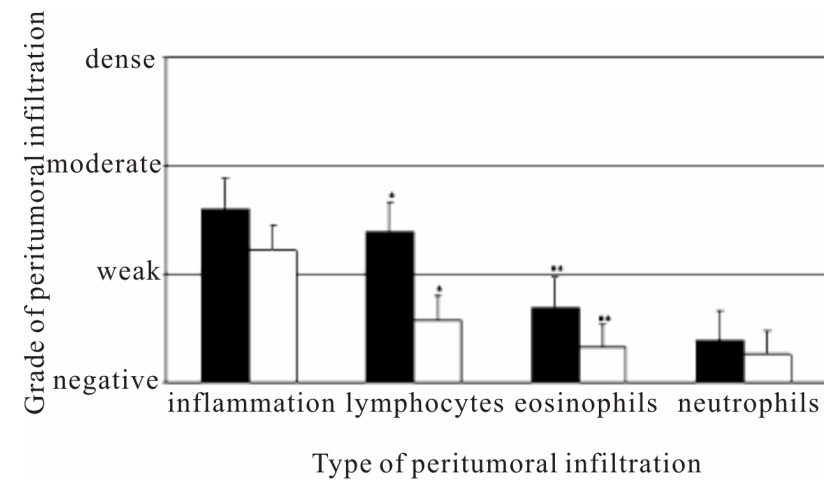

Figure 3. Grade of peritumoral infiltration. Peritumoral infiltration was graded through a semiquantitative method (see Figure 3). Grade_s averages of peritumoral infiltration resulted significant increased in patients treated with lowdose IL-2 (black bars) compared to controls (white bars), for lymphocytes $(p=0.0003)$ and eosinophils $(p=0.0249)$.

related with a low tumor stage and younger age at presentation. Although less significant, overall survival also appeared to be affected by the type of surgical intervention. Total gastrectomy resulted in a worse prognosis than partial gastrectomy and this might relate to the fact that total gastrectomy was chosen more frequently for cardia tumors, which have been described as being more aggressive than tumors affecting other parts of the stomach. In addition these results might also relate to the fact that gastrectomy is a bigger procedure and may lead to more profound immunosuppression, although we did not find this in our study. The fact that relapse-free survival did not depend on the type of surgical intervention might have been related to appropriate selection of patients for surgical intervention and good operative technique.

\section{Conclusion}

According to our data low doses of IL-2 administered pre-operatively to patients with gastric cancer activate peripheral and peri-tumoral lymphocytes but did not affect prognosis and Kaplan-Meier analysis suggested no differences between cases and controls (Figure 4). The reasons for the lack of therapeutic effectiveness are not entirely clear but we would propose several points for consideration. Firstly, we know that only selected melanoma and renal cell carcinoma patients have a significant benefit from high-dose IL-2 therapy and for this reason we may require a much larger study to detect a benefit in patients with gastric carcinoma. Secondly, we utilized a low-dose IL-2 regimen and most studies with IL-2 have found that high-dose therapy is superior to low-dose treatment regimens [176]. Finally, the influence of IL-2 on regulatory $\mathrm{T}$ cells may be critical for influencing clinical outcome and we did not directly examine these cells in the current study. While many reports suggest that these regulatory $\mathrm{T}$ cells are elevated in cancer pa-

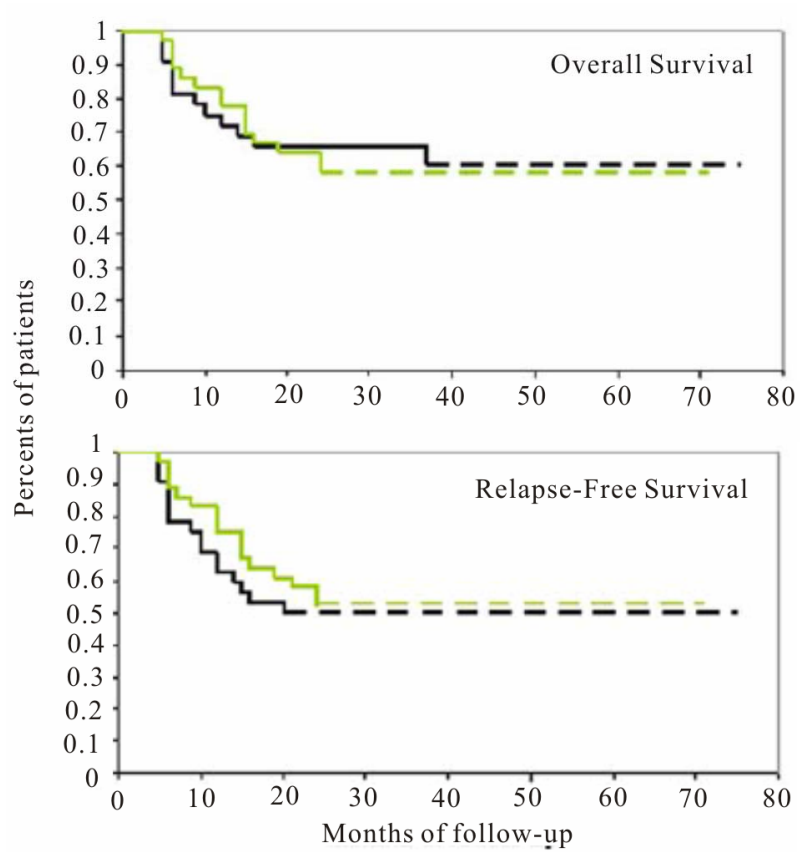

Figure 4. Kaplan-Meier curves shows that there is no significant difference in overall survival and in relapse-free survival, between patients treated with low-dose IL-2 (dark line) and controls (light line).

tients, there are some data suggesting that high-dose IL-2 may be associated with a decrease to normal levels of this population after exposure to high-dose IL-2 [84]. Thus, further investigation with high-dose IL-2 and careful monitoring of regulatory $\mathrm{T}$ cell populations may provide further insights into the utility of IL-2 and other forms of immunotherapy for patients with gastric cancer.

\section{REFERENCES}

[1] D. M. Parkin, F. Bray, J. Ferlay, et al., "Global Cancer Statistics, 2002," CA: A Cancer Journal for Clinicians, Vol. 55, No. 2, 2005, pp. 74-108. doi:10.3322/canjclin.55.2.74

[2] "Schistosomes, Liver Flukes and Helicobacter pylori," IARC Monograph on the Evaluation of Carcinogenic Risks to Humans, Vol. 61, International Agency for Research on Cancer, Lyon, 1994.

[3] "Tobacco Smoke and Involuntary Smoking IARC," Monographs on the Evaluation of Carcinogenic Risk to Humans, Vol. 83, International Agency for Research on Cancer, Lyon, 2004.

[4] D. M. Roder, "The Epidemiology of Gastric Cancer," Gastric Cancer, Vol. 5, No. 1, 2002, pp. 5-11. doi:10.1007/s10120-002-0203-6

[5] D. M. Parkin, S. L. Whelan, J. Ferlay, et al., "Cancer Incidence in Five Continents," Volume VII, IARC Scientific Publications No. 143, International Agency for Research on Cancer, Lyon, 1997.

[6] A. Nomura, "Stomach Cancer," In: D. Schottenfeld and J. 
F. Fraumeni, Eds., Cancer Epidemiology and Prevention, Oxford University Press, New York, 1996, pp. 707-724.

[7] P. Correa and V. Chen, "Gastric Cancer," In: R. Doll, J. F. Fraumeni and C. S. Muir, Eds., Trends in Cancer Incidence and Mortality, Cold Spring Harbor Laboratory Press, Cold Spring Harbor, 1994, pp. 55-76.

[8] W. J. Blot, S. S. Devesa, R. W. Kneller, et al., "Rising Incidence of Adenocarcinoma of the Esophagus and Gastric Cardia," Journal of the American Medical Association, Vol. 265, No. 10, 1991, pp. 1287-1289. doi:10.1001/jama.1991.03460100089030

[9] J. S. Macdonald, M. C. Hill and I. M. Roberts, "Gastric Cancer: Epidemiology, Pathology, Detection and Staging," In: J. D. Ahlgren and J. S. Macdonald, Eds., Gastrointestinal Oncology, J.B. Lippincott, Philadelphia, 1992, pp. 151-158.

[10] D. M. Parkin, P. Pisani and J. Ferlay, "Estimates of the Worldwide Incidence of Eighteen Major Cancers in 1985," International Journal of Cancer, Vol. 54, No. 4, 1993, pp. 594-606. doi:10.1002/ijc.2910540413

[11] C. J. Clark, R. C. Thirlby, V. Picozzi Jr., et al., "Current Problems in Surgery: Gastric Cancer," Current Problems in Surgery, Vol. 43, No. 8, 2006, pp. 566-670. doi:10.1067/j.cpsurg.2006.06.003

[12] S. A. Hundahl, H. R. Menck, E. G. Mansour, et al., "The National Cancer Database Report on Gastric Carcinoma," Cancer, Vol. 80, No. 12, 1997, pp. 2333-2341. doi:10.1002/(SICI)1097-0142(19971215)80:12<2333::AI D-CNCR15>3.0.CO;2-V

[13] V. Spataro, M. Genoni, C. Maurer, et al., "Stomach Cancer: 10 Years' Experience with Surgical Treatment and Possibilities for Improving the Prognosis," Helvetica Chirurgica Acta, Vol. 59, No. 4, 1993, pp. 589-595.

[14] A. M. G. Bunt, J. Hermans, V. T. Smit, et al., "Surgical/ Pathologic-Stage Migration Confounds Comparisons of Gastric Cancer Survival Rates between Japan and Western Countries," Journal of Clinical Oncology, Vol. 13, No. 1, 1995, pp. 19-25.

[15] L. E. Harrison, M. S. Karpeh and M. F. Brennan, "Extended Lymphadenectomy Is Associated with a Survival Benefit for Node-Negative Gastric Cancer," Journal of Gastrointestinal Surgery, Vol. 2, No. 2, 1998, pp. 126131. doi:10.1016/S1091-255X(98)80002-4

[16] A. Cuschieri, S. Weeden, J. Fielding, et al., "Patient Survival after D1 and D2 Resections for Gastric Cancer: Long-Term Results of the MRC Randomized Surgical Trial," British Journal of Cancer, Vol. 79, No. 9-10, 1999, pp. 1522-1530. doi:10.1038/sj.bjc.6690243

[17] J. J. Bonenkamp, J. Hermans, M. Sasako, et al., "Extended Lymph-Node Dissection for Gastric Cancer," The New England Journal of Medicine, Vol. 340, No. 12, 1999, pp. 908-914. doi:10.1056/NEJM199903253401202

[18] P. McCulloch, M. E. Nita, H. Kazi, et al., "Extended versus Limited Lymph Nodes Dissection Technique for Adenocarcinoma of the Stomach," Cochrane Database of Systematic Reviews, No. 4, 2004, Article ID: CD001964.

[19] C. C. Earle and J. A. Maroun, "Adjuvant Chemotherapy after Curative Resection for Gastric Cancer in Non-Asian
Patients: Revisiting a Meta-Analysis of Randomized Trials," European Journal of Cancer, Vol. 35, No. 7, 1999, pp. 1059-1064. doi:10.1016/S0959-8049(99)00076-3

[20] J. Hermans, J. J. Bonenkamp, M. C. Boon, et al., “Adjuvant Therapy after Curative Resection for Gastric Cancer: Meta-Analysis of Randomized Trials," Journal of Clinical Oncology, Vol. 11, No. 8, 1993, pp. 1441-1447.

[21] J. S. Macdonald, S. R. Smalley, J. Benedetti, et al., "Chemoradiotherapy after Surgery Compared with Surgery alone for Adenocarcinoma of the Stomach or Gastroesophageal Junction," The New England Journal of Medicine, Vol. 345, No. 10, 2001, pp. 725-730. doi:10.1056/NEJMoa010187

[22] T. Andre, C. Boni, L. Mounedji-Boudiaf, et al., "Oxaliplatin, Fluorouracil, and Leucovorin as Adjuvant Treatment for Colon Cancer," The New England Journal of Medicine, Vol. 350, No. 23, 2004, pp. 2343-2351. doi:10.1056/NEJMoa032709

[23] Y. Flamant, J. Chipponi, M. Huguier, et al., AURC, ARC, "Chimiothérapie Adjuvante Après Résection des Adénocarcinomes Gastriques: Etude Prospective Contrôlée de l'Effet de 1'Association 5FU, Acide Folinique et Cisplatine," Gastroentérologie Clinique et Biologique, Vol. 23, No. 16A, 1999.

[24] S. Koga, R. Hamazoe, M. Maeta, et al., "Prophylactic Therapy for Peritoneal Recurrence of Gastric Cancer by Continuous Hyperthermic Peritoneal Perfusion with Mitomycin C," Cancer, Vol. 61, No. 2, 1988, pp. 323-327. doi:10.1002/1097-0142(19880115)61:2<232::AID-CNCR $\underline{2820610205>3.0 . \mathrm{CO} ; 2-\mathrm{U}}$

[25] A. Hagiwara, T. Takahaschi, O. Kojima, et al., "Prophylaxis with Carbon-Absorbed Mitomycin against Peritoneal Recurrence of Gastric Cancer," Lancet, Vol. 339, No. 8794, 1992, pp. 629-631. doi:10.1016/0140-6736(92)90792-2

[26] R. Hamazoe, M. Maeta and N. Kaibara, "Intraperitoneal Thermochemotherapy for Prevention of Peritoneal Recurrence of Gastric Cancer. Final Results of a Randomized Controlled Study," Cancer, Vol. 73, No. 8, 1994, pp. 20482052.

doi:10.1002/1097-0142(19940415)73:8<2048::AID-CNC R2820730806>3.0.CO;2-Q

[27] T. Fujimura, Y. Yonemura, K. Muraoka, et al., "Continuous Hyperthermic Peritoneal Perfusion for the Prevention of Peritoneal Recurrence of Gastric Cancer, Randomized Controlled Study," World Journal of Surgery, Vol. 18, No. 1, 1994, pp. 150-155. doi:10.1007/BF00348209

[28] W. Yu, I. Whang, I. Suh, et al., "Prospective Randomized Trial of Early Postoperative Intraperitoneal Chemotherapy as an Adjuvant to Resectable Gastric Cancer," Annals of Surgery, Vol. 228, No. 3, 1998, pp. 347-354. doi:10.1097/00000658-199809000-00007

[29] P. Van der Bruggen, C. Traversari, P. Chomez, et al., "A Gene Encoding an Antigen Recognized by Cytolytic T Lymphocytes on a Human Melanoma," Science, Vol. 254, No. 5038, 1991, pp. 1643-1647. doi:10.1126/science. 1840703

[30] D. Pardoll, "Does the Immune System See Tumors as Foreign or Self?" Annual Review of Immunology, Vol. 21, 
No. 1, 2003, pp. 807-839. doi:10.1146/annurev.immunol.21.120601.141135

[31] E. R. Fearon and B. A. Vogelstein, "Genetic Model for Colorectal Tumorogenesis,” Cell, Vol. 61, No. 5, 1990, pp. 759-767. doi:10.1016/0092-8674(90)90186-I

[32] L. Thomas, "Discussion," In: H. S. Lawrence, Ed., Cellular and Humoral Aspects of the Hypersensitive States," Hoeber-Harper, New York, 1959, pp. 529-532.

[33] F. M. Burnet, "The Concept of Immunological Surveillance," Progress in Experimental Tumor Research, Vol. 13, 1970, pp. 1-27.

[34] S. Shu, G. E. Plautz, J. C. Krauss, et al., "Tumor Immunology," JAMA, Vol. 278, No. 22, 1997, pp. 1972-1981. doi:10.1001/jama.1997.03550220178023

[35] H. T. Khong and N. P. Restifo, "Natural Selection of Tumor Variants in the Generation of 'Tumor Escape' Phenotypes," Nature Immunology, Vol. 3, No. 11, 2002, pp. 999-1005. doi:10.1038/ni1102-999

[36] F. Esteban, A. Concha, M. Delgado, et al., "Lack of MHC Class I Antigens and Tumour Aggressiveness of the Squamous Cell Carcinoma of the Larynx," British Journal of Cancer, Vol. 62, 1990, pp. 1047-1051. doi:10.1038/bjc. 1990.437

[37] F. Esteban, A. Concha, C. Huelin, et al., "Histocompatibility Antigens in Primary and Metastatic Squamous Cell Carcinoma of the Larynx," International Journal of Cancer, Vol. 43, No. 3, 1989, pp. 436-442. doi:10.1002/ijc.2910430316

[38] F. Esteban, M. Redondo, M. Delgado, et al., "MHC Class I Antigens and Tumour-Infiltrating Leucocytes in Larynal Cancer: Long-Term Follow-Up," British Journal of Cancer, Vol. 74, 1996, pp. 1801-1804. doi:10.1038/bjc. 1996.633

[39] S. Ferrone and F. M. Marincola, "Loss of HLA Class I Antigens by Melanoma Cells: Molecular Mechanisms, Functional Significance and Clinical Relevance," Immunol Today, Vol. 16, 1995, pp. 487-494. doi:10.1016/0167-5699(95)80033-6

[40] P. G. Natali, A. Bigotti, M. R. Nicotra, et al., "Distribution of Human Class I (HLA-A,B,C) Histocompatibility Antigens in Normal and Malignant Tissues of Nonlymphoid Origin," Cancer Research, Vol. 44, No. 10, 1984, pp. 4679-4687.

[41] P. Natali, A. Bigotti, R. Cavaliere, et al., "Heterogeneous Expression of Melanoma-Associated Antigens and HLA Antigens by Primary and Multiple Metastatic Lesions Removed from Patients with Melanoma," Cancer Research, Vol. 45, No. 6, 1985, pp. 2883-2889.

[42] P. G. Natali, R. Cavaliere, A. Bigotti, et al., "Antigenic Heterogeneity of Surgically Removed Primary and Autologous Metastatic Human Melanoma Lesions," Journal of Immunology, Vol. 130, No. 3, 1983, pp. 1462- 1466.

[43] P. G. Natali, M. R. Nicotra, A. Bigotti, et al., "Selective Changes in Expression of HLA Class I Polymorphic Determinants in Human Solid Tumors," Proceedins of the National Academy of Science of the United States of America, Vol. 86, No. 17, 1989, pp. 6719-6723. doi:10.1073/pnas.86.17.6719
[44] M. Perez, T. Cabrero, M. A. Lopez Nevot, et al., "Heterogeneity of the Expression of Class I and II HLA Antigens in Human Breast Carcinoma," International Journal of Immunogenetics, Vol. 13, No. 2-3, 1986, pp. 247-253. doi:10.1111/j.1744-313X.1986.tb01108.x

[45] H. L. Whitwell, H. P. Hughes, M. Moore, et al., "Expression of Major Histocompatibility Antigens and Leucocyte Infiltration in Benign and Malignant Human Breast Disease," British Journal of Cancer, Vol. 49, 1984, pp. 161172. doi:10.1038/bjc. 1984.28

[46] J. A. Zuk and R. A. Walker, "Immunohistochemical Analysis of HLA Antigens and Mononuclear Infiltrates of Benign and Malignant Breast," The Journal of Pathology, Vol. 152, No. 4, 1987, pp. 275-285. doi:10.1002/path.1711520406

[47] F. Ruiz-Cabello, M. A. Lopez Nevot, J. Gutierrez, et al., "Phenotypic Expression of Histocompatibility Antigens in Human Primary Tumours and Metastases," Clinical \& Experimental Metastasis, Vol. 7, No. 2, 1989, pp. 213226. doi:10.1007/BF01787025

[48] F. Ruiz-Cabello, M. Perez-Ayala, O. Gomez, et al., "Molecular Analysis of MHC-Class-I Alterations in Human Tumor Cell Lines," International Journal of Cancer, Vol. 47, Suppl. 6, 1991, pp. 123-130. doi:10.1002/ijc.2910470723

[49] T. Cabrera, M. A. Fernandez, A. Sierra, et al., "High Frequency of Altered HLA Class I Phenotypes in Invasive Breast Carcinomas," Human Immunology, Vol. 50, No. 2, 1996, pp. 127-134. doi:10.1016/0198-8859(96)00145-0

[50] T. Cabrera, A. Collado, M. A. Fernandez, et al., "High Frequency of Altered HLA Class I Phenotypes in Invasive Colorectal Carcinomas," Tissue Antigens, Vol. 52, No. 2, 1988, pp. 114-123. doi:10.1111/j.1399-0039.1998.tb02274.x

[51] H. F. van den Ingh, D. J. Ruiter, G. Griffioen, et al., "HLA Antigens in Colorectal Tumours-Low Expression of HLA Class I Antigens in Mucinous Colorectal Carcinomas," British Journal of Cancer, Vol. 55, 1987, pp. 125130. doi:10.1038/bjc.1987.26

[52] W. J. van Driel, M. Y. Tjiong, C. G. Hilders, et al., “Association of Allele-Specific HLA Expression and Histopathologic Progression of Cervical Carcinoma," Gynecologic Oncology, Vol. 62, No. 1, 1996, pp. 33-41. doi:10.1006/gyno.1996.0186

[53] R. H. Schwartz, "A Cell Culture Model for T Lymphocyte Clonal Anergy," Science, Vol. 248, No. 4961, 1990, pp. 1349-1356.doi:10.1126/science.2113314

[54] L. Chen, P. McGowan, S. Ashe, et al., "Tumor Immunogenicity Determines the Effect of B7 Costimulation on T Cell-Mediated Tumor Immunity," The Journal of Cell Biology, Vol. 179, No. 2, 1994, pp. 523-532. doi:10.1084/jem.179.2.523

[55] H. Schreiber, T. H. Wu, J. Nachman, et al., "Immunodominance and Tumor Escape," Seminars in Cancer Biology, Vol. 12, No. 1, 2002, pp. 25-31. doi:10.1006/scbi.2001.0401

[56] K. Takeda, M. J. Smyth, E. Cretney, et al., "Critical Role for Tumor Necrosis Factor-Related Apoptosis-Inducing Ligand in Immune Surveillance against Tumor Develop- 
ment," The Journal of Cell Biology, Vol. 195, No. 2, 2002, pp. 161-169. doi:10.1084/jem.20011171

[57] S. E. Straus, E. S. Jaffe, J. M. Puck, et al., "The Development of Lymphomas in Families with Autoimmune Lymphoproliferative Syndrome with Germline Fas Mutations and Defective Lymphocyte Apoptosis," Blood, Vol. 98, No. 1, 2001, pp. 194-200. doi:10.1182/blood.V98.1.194

[58] W. F. Davidson, T. Giese and T. N. Fredrickson, "Spontaneous Development of Plasmacytoid Tumors in Mice with Defective Fas-Fas Ligand Interactions," The Journal of Cell Biology, Vol. 187, No. 11, 1998, pp. 1825-1838. doi:10.1084/jem.187.11.1825

[59] K. Takeda, Y. Hayakawa, M. J. Smyth, et al., "Involvement of Tumor Necrosis Factor-Related Apoptosis-Inducing Ligand in Surveillance of Tumor Metastasis by Liver Natural Killer Cells," Nature Medicine, Vol. 7, No. 1, 2001, pp. 94-100.

[60] T. H. Landowski, N. Qu, I. Buyuksal, et al., "Mutations in the Fas Antigen in Patients with Multiple Myeloma," Blood, Vol. 90, No. 11, 1997, pp. 4266-4270.

[61] K. Gronbaek, P. T. Straten, E. Ralfkiaer, et al., "Somatic Fas Mutations in Non-Hodgkin's Lymphoma: Association with Extranodal Disease and Autoimmunity," Blood, Vol. 92, No. 9, 1998, pp. 3018-3024.

[62] M. S. Shin, W. S. Park, S. Y. Kim, et al., "Alterations of Fas (Apo-1/CD95) Gene in Cutaneous Malignant Melanoma," The American Journal of Pathology, Vol. 154, No. 6, 1999, pp. 1785-1791. doi:10.1016/S0002-9440(10)65434-X

[63] M. S. Shin, H. S. Kim, S. H. Lee, et al., "Alterations of Fas-Pathway Genes Associated with Nodal Metastasis in Non-Small Cell Lung Cancer," Oncogene, Vol. 21, No. 26, 2002, pp. 4129-4136. doi:10.1038/sj.onc. 1205527

[64] M. S. Shin, H. S. Kim, C. S. Kang, et al., "Inactivating Mutations of CASP10 Gene in Non-Hodgkin Lymphomas," Blood, Vol. 99, 2002, pp. 4094-4099. doi:10.1182/blood.V99.11.4094

[65] M. Toi, T. Taniguchi, Y. Yamamoto, et al., "Clinical Significance of the Determination of Angiogenic Factors," European Journal of Cancer, Vol. 32, No. 14, 1996, pp. 2513-2519. doi:10.1016/S0959-8049(96)00397-8

[66] T. Oyama, S. Ran, T. Ishida, et al., "Vascular Endothelial Growth Factor Affects Dendritic Cell Maturation through the Inhibition of Nuclear Factor- $\kappa$ B Activation in Hemopoietic Progenitor Cells," The Journal of Immunology, Vol. 160, 1998, pp. 1224-1232.

[67] H. Saito, S. Tsujitani, M. Ikeguchi, et al., "Relationship between the Expression of Vascular Endothelial Growth Factor and the Density of Dendritic Cells in Gastric Adenocarcinoma Tissue," British Journal of Cancer, Vol. 78, 1998, pp. 1573-1577. doi:10.1038/bjc.1998.725

[68] B. Almand, J. R. Resser, B. Lindman, et al., "Clinical Significance of Defective Dendritic Cell Differentiation in Cancer," Clinical Cancer Research, Vol. 6, No. 5, 2000, pp. 1755-1766.

[69] G. Girolomoni and P. Ricciardi-Castagnoli, "Dendritic Cells Hold Promise for Immunotherapy," Trends in Im- munology, Vol. 18, No. 3, 1997, pp. 102-104. doi:10.1016/S0167-5699(97)01030-X

[70] T. de Smedt, M. van Mechelen, G. de Becker, et al., "Effect of Interleukin-10 on Dendritic Cell Maturation and Function," European Journal of Immunology, Vol. 27, No. 5, 1997, pp. 1229-1235. doi:10.1002/eji.1830270526

[71] S. Sharma, M. Stolina, Y. Lin, et al., "T Cell-Derived IL-10 Promotes Lung Cancer Growth by Suppressing both T Cell and APC Function," Journal of Immunology, Vol. 163, No. 9, 1999, pp. 5020-5028.

[72] B. Ludewig, D. Graf, H. R. Gelderblom, et al., "Spontaneous Apoptosis of Dendritic Cells Is Efficiently Inhibited by TRAP (CD40-Ligand) and TNF- $\alpha$, but Strongly Enhanced by Interleukin-10," European Journal of Immunology, Vol. 25, No. 7, 1995, pp. 1943-1950. doi:10.1002/eji.1830250722

[73] F. Y. Yue, R. Dummer, R. Geertsen, et al., "Interleukin-10 Is a Growth Factor for Human Melanoma Cells and Down-Regulates HLA Class-I, HLA Class-II and ICAM1 Molecules," International Journal of Cancer, Vol. 71, No. 4, 1997, pp. 630-637.

doi:10.1002/(SICI)1097-0215(19970516)71:4<630::AIDIJC20>3.0.CO;2-E

[74] B. Sadlack, H. Merz, H. Schorle, et al., "Ulcerative Colitis-Like Disease in Mice with a Disrupted Interleukin-2 Gene," Cell, Vol. 75, No. 2, 1993, pp. 253-261. doi:10.1016/0092-8674(93)80067-O

[75] B. Sadlack, R. Kuhn, H. Schorle, et al., "Development and Proliferation of Lymphocytes in Mice Deficient for Both Interleukins-2 and -4," European Journal of Immunology, Vol. 24, No. 1, 1994, pp. 281-284. doi:10.1002/eji.1830240144

[76] B. Sadlack, J. Lohler, H. Schorle, et al., "Generalized Autoimmune Disease in Interleukin-2-Deficient Mice Is Triggered by an Uncontrolled Activation and Proliferation of CD4 ${ }^{+}$T Cells," European Journal of Immunology, Vol. 25, 1995, pp. 3053-3059. doi:10.1002/eji.1830251111

[77] E. M. Shevach, "CD4 ${ }^{+} \mathrm{CD} 25^{+}$Suppressor T Cells: More Questions than Answers," Nature Reviews. Immunology, Vol. 2, No. 6, 2002, pp. 389-400.

[78] A. M. Wolf, D. Wolf, M. Steurer, et al., "Increase of Regulatory T Cells in the Peripheral Blood of Cancer Patients," Clinical Cancer Research, Vol. 9, No. 2, 2003, pp. 606-612.

[79] U. K. Liyanage, T. T. Moore, H. G. Joo, et al., "Prevalence of Regulatory $\mathrm{T}$ Cells Is Increased in Peripheral Blood and Tumor Microenvironment of Patients with Pancreas or Breast Adenocarcinoma," Journal of Immunology, Vol. 169, 2002, pp. 2756-2761.

[80] E. Y. Woo, H. Yeh, C. S. Chu, et al., "Cutting Edge: Regulatory T Cells from Lung Cancer Patients Directly Inhibit Autologous T Cell Proliferation," Journal of Immunology, Vol. 168, No. 9, 2002, pp. 4272-4276.

[81] F. Ichihara, K. Kono, A. Takahashi, et al., "Increased Populations of Regulatory T Cells in Peripheral Blood and Tumor-Infiltrating Lymphocytes in Patients with Gastric and Esophageal Cancers," Clinical Cancer Research, Vol. 9, No. 12, 2003, pp. 4404-4408. 
[82] L. A. Ormandy, T. Hillemann, H. Wedemeyer, et al., "Increased Populations of Regulatory T Cells in Peripheral Blood of Patients with Hepatocellular Carcinoma," Cancer Research, Vol. 65, No. 6, 2005, pp. 2457-2464. doi:10.1158/0008-5472.CAN-04-3232

[83] T. Sasada, M. Kimura, Y. Yoshida, et al., "CD4 ${ }^{+} \mathrm{CD} 25^{+}$ Regulatory $\mathrm{T}$ Cells in Patients with Gastrointestinal Malignancies: Possible Involvement of Regulatory T Cells in Disease Progression," Cancer, Vol. 98, No. 5, 2003, pp. 1089-1099. doi:10.1002/cncr.11618

[84] G. C. Cesana, G. DeRaffele, S. Cohen, et al., "Characterization of $\mathrm{CD}^{+} \mathrm{CD} 25^{+}$Regulatory $\mathrm{T}$ Cells in Patients Treated with High-Dose Interleukin-2 for Metastatic Melanoma or Renal Cell Carcinoma," Journal of Clinical Oncology, Vol. 24, No. 7, 2006, pp. 1169-1177. doi:10.1200/JCO.2005.03.6830

[85] T. W. Lennard, B. K. Shenton, A. Borzotta, et al., "The Influence of Surgical Operations on Components of the Human Immune System," British Journal of Surgery, Vol. 72, No. 10, 1985, pp. 771-776. doi:10.1002/bjs. 1800721002

[86] C. H. Wakefield, P. D. Carey, S. Foulds, et al., "Changes in Major Histocompatibility Complex Class II Expression in Monocytes and T Cells of Patients Developing Infection after Surgery," British Journal of Surgery, Vol. 80, No. 2, 1993, pp. 205-209. doi:10.1002/bjs.1800800224

[87] W. G. Cheadle, M. J. Hershman, S. R. Wellhausen, et al., "HLA-DR Antigen Expression on Peripheral Blood Monocytes Correlates with Surgical Infection," American Journal of Surgery, Vol. 161, No. 6, 1991, pp. 639-645.

[88] A. M. M. Eggermont, E. P. Steller, P. H. Sugerbacker, "Laparotomy Enhances Intraperitoneal Tumour Growth and Abrogates the Antitumor Effects of Interleukin-2 and Lymphokine-Activated Killer Cells," Surgery, Vol. 102, No. 1, 1987, pp. 71-78.

[89] T. Hensler, H. Hecker, K. Heeg, et al., "Distinct Mechanisms of Immunosuppression as a Consequence of Major Surgery," Infection and Immunity, Vol. 65, No. 6, 1997, pp. 2283-2291.

[90] P. Sheeran and G. M. Hall, "Cytokines in Anaesthesia," British Journal of Anaesthesia, Vol. 78, No. 2, 1997, pp. 201-219. doi:10.1093/bja/78.2.201

[91] H. Baumann and J. Gauldie, "The Acute Phase Response," Immunology Today, Vol. 15, No. 2, 1994, pp. 74-80. doi:10.1016/0167-5699(94)90137-6

[92] R. M. Roumen, T. Hendriks, J. van der Ven-Jongekrijg, et al., "Cytokine Patterns in Patients after Major Vascular Surgery, Hemorrhagic Shock, and Severe Blunt Trauma. Relation with Subsequent Adult Respiratory Distress Syndrome and Multiple Organ Failure," Annals of Surgery, Vol. 218, No. 6, 1993, pp. 769-776. doi:10.1097/00000658-199312000-00011

[93] R. J. Baigrie, P. M. Lamont, D, Kwiatkowski, et al., "Systemic Cytokine Response after Major Surgery," British Journal of Surgery, Vol. 79, No. 8, 1992, pp. 757-760. doi:10.1002/bjs.1800790813

[94] J. P. Desborough, "The Stress Response to Trauma and Surgery," British Journal of Anaesthesia, Vol. 85, No. 1, 2000, pp. 109-117. doi:10.1093/bja/85.1.109
[95] A. M. Cruickshank, W. D. Fraser, H. J. Burns, et al., "Response of Serum Interleukin-6 in Patients Undergoing Elective Surgery of Varying Severity," Clinical Science, Vol. 79, No. 2, 1990, pp. 161-165.

[96] F. Glaser, G. A. Sannwald, H. J. Buhr, et al., "General Stress Response to Conventional and Laparoscopic Cholecystectomy," Annals of Surgery, Vol. 221, No. 4, 1995, pp. 372-380. doi:10.1097/00000658-199504000-00007

[97] T. Kloosterman, B. M. von Blomberg, P. Borgstein, M. A. Cuesta, R. J. Scheper and S. Meijer, "Unimpaired Immune Functions after Laparoscopic Cholecystectomy," Surgery, Vol. 115, No. 4, 1994, pp. 424-428.

[98] H. Ueo, M. Honda, M. Adachi, et al., "Minimal Increase in Serum Interleukin-6 Levels during Laparoscopic Cholecystectomy," The American Journal of Surgery, Vol. 168, No. 4, 1994, pp. 358-360. doi:10.1016/S0002-9610(05)80166-7

[99] U. Hildebrandt, K. Kessler, G. Pistorius, et al., "Granulocyte Elastase and Systemic Cytokine Response after Laparoscopic-Assisted and Open Resections in Crohn's Disease," Diseases of the Colon \& Rectum, Vol. 42, No. 11, 1999, pp. 1480-1486. doi:10.1007/BF02235052

[100] U. Hildebrandt, K. Kessler, T. Plusczyk, et al., "Comparison of Surgical Stress between Laparoscopic and Open Colonic Resections," Surgical Endoscopy And Other Interventional Techniques, Vol. 17, No. 2, 2003, pp. 242246. doi:10.1007/s00464-001-9148-9

[101] A. J. Botha, F. A. Moore, E. E. Moore, et al., "Early Neutrophil Sequestration after Injury: A Pathogenic Mechanism for Multiple Organ Failure," The Journal of Trauma, Vol. 39, No. 3, 1996, pp. 411-417.

[102] H. P. Redmond, R. W. Watson, T. Houghton, et al., "Immune Function in Patients Undergoing Open vs Laparoscopic Cholecystectomy," Archives of Surgery, Vol. 129, No. 12, 1994, pp. 1240-1246. doi:10.1001/archsurg.1994.01420360030003

[103] W. L. Biffl, E. E. Moore, F. A. Moore, et al., "Interleukin-6 in the Injured Patient. Marker of Injury or Mediator of Inflammation?" Annals of Surgery, Vol. 224, No. 5, 1996, pp. 647-664. doi:10.1097/00000658-199611000-00009

[104] R. P. Phipps, S. H. Stein and R. L. Roper, "A New View of Prostaglandin E Regulation of the Immune Response," Immunology Today, Vol. 12, No. 10, 1991, pp. 349-352. doi:10.1016/0167-5699(91)90064-Z

[105] A. Ayala, D. L. Lehman, C. D. Herdon, et al., "Mechanism of Enhanced Susceptibility to Sepsis Following Hemorrhage. Interleukin-10 Suppression of T-Cell Response Is Mediated by Eicosanoid-Induced Interleukin-4 Release," Archives of Surgery, Vol. 129, No. 11, 1994, pp. 1172-1178. doi:10.1001/archsurg.1994.01420350070009

[106] D. Mokart, C. Capo, J. L. Blache, et al., "Early Postoperative Compensatory Anti-Inflammatory Response Syndrome Is Associated with Septic Complications after Major Surgical Trauma in Patients with Cancer," British Journal of Surgery, 2002, Vol. 89, No. 11, pp. 14501456. doi:10.1046/j.1365-2168.2002.02218.x

[107] M. Ogata, K. Okamoto, K. Kohriyama, et al., "Role of Interleukin-10 on Hyporesponsiveness of Endotoxin dur- 
ing Surgery," Critical Care Medicine, Vol. 28, No. 9, 2000, pp. 3166-3170. doi:10.1097/00003246-200009000-00007

[108] I. B. Brune, W. Wilke, T. Hensler, et al., "Downregulation of T Helper Type 1 Immune Response and Altered Pro-Inflammatory and Anti-Inflammatory T Cell Cytokine Balance Following Conventional but Not LaparoScopic Surgery," The American Journal of Surgery, Vol. 177 , No. 1,1999 , pp. 55-60. doi:10.1016/S0002-9610(98)00299-2

[109] E. Faist, C. Schinkel and S. Zimmer, "Update on the Mechanisms of Immune Suppression of Injury and Immune Modulation," World Journal of Surgery, Vol. 20, No. 4, 1996, pp. 454-459. doi:10.1007/s002689900071

[110] W. D. Döcke, F. Randow, U. Syrbe, et al., "Monocyte Deactivation in Septic Patients: Restoration by IFNGamma Treatment," Nature Medicine, Vol. 3, 1997, pp. 678-681. doi:10.1038/nm0697-678

[111] G. Strassmann, V. Patil-Koota, F. Finkelman, et al., "Evidence for the Involvement of Interleukin 10 in the Differential Deactivation of Murine Peritoneal Macrophages by Prostaglandin E2," The Journal of Cell Biology, Vol. 180 , No. 6, 1994, pp. 2365-2370. doi:10.1084/jem.180.6.2365

[112] A. Ayala, D. R. Meldrum, M. M. Perrin, et al., "The Release of Transforming Growth Factor-Beta Following Haemorrhage: Its Role as a Mediator of Host Immunosuppression," Immunology, Vol. 79, No. 3, 1993, pp. 479484.

[113] H. M. Hafez, C. S. Berwanger, P. Lintott, et al., "Endotoxemia during Supraceliac Aortic Crossclamping Is Associated with Suppression of the Monocyte CD14 Mechanism: Possible Role of Transforming Growth Factor-beta1," Journal of Vascular Surgery, Vol. 31, No. 3, 2000, pp. 520-531. doi:10.1016/S0741-5214(00)90314-8

[114] A. Dietz, F. Heimlich, V. Daniel, et al., "Immunomodulating Effects of Surgical Intervention in Tumors of the Head and Neck," Otolaryngology-Head and Neck Surgery, Vol. 123, No. 1, 2000, pp. 132-139. doi: $10.1067 / \mathrm{mhn} .2000 .104669$

[115] G. Delogu, S. Moretti, A. Antonucci, et al., "Apoptosis and Surgical Trauma: Dysregulated Expression of Death and Survival Factors on Peripheral Lymphocytes," Archives of Surgery, Vol. 135, No. 10, 2000, pp. 1141-1147. doi:10.1001/archsurg.135.10.1141

[116] G. Delogu, G. Famularo, S. Moretti, et al., "Interleukin10 and Apoptotic Death of Circulating Lymphocytes in Surgical/Anesthesia Trauma," The Journal of Trauma, Vol. 51, No. 1, 2001, pp. 92-97.

[117] Y. Wang, Q. Gu, B. Liu, et al., "Perspectives of SEREXDefined Antigens in Diagnosis and Immunotherapy for Gastric Cancer," Cancer Biology \& Therapy, Vol. 3, No. 9, 2004, pp. 806-811. doi:10.4161/cbt.3.9.1140

[118] P. Lissoni, F. Brivio, A. Ardizzoia, et al., "Subcutaneous Therapy with Low-Dose Interleukin-2 Plus the Neurohormone Melatonin in Metastatic Gastric Cancer Patients with Low Performance Status," Tumori, Vol. 79, No. 6, 1993, pp. 401-404.

[119] P. Lissoni, S. Barni, A. Ardizzoia, et al., "Cancer Immu- notherapy with Low-Dose Interleukin-2 Subcutaneous Administration: Potential Efficacy in Most Solid Tumor Histotypes by a Concomitant Treatment with the Pineal Hormone Melatonin," Journal of Biological Regulators and Homeostatic Agents, Vol. 7, No. 4, 1993 pp. 121125.

[120] A. Gochi, K. Orita, S. Fuchimoto, et al., "The Prognostic Advantage of Preoperative Intratumoral Injection of OK432 for Gastric Cancer Patients," British Journal of Cancer, Vol. 84, No. 4, 2001, pp. 443-451. doi:10.1054/bjoc. 2000.1599

[121] F. Romano, G. Cesana, R. Caprotti, et al., "Preoperative IL-2 Immunotherapy Enhances Tumor Infiltrating Lymphocytes (TILs) in Gastric Cancer Patients," Hepatogastroenterology, Vol. 53, No. 70, 2006, pp. 634-648.

[122] Y. Sato, M. Kondo, S. Kohashi, et al., "A Randomized Controlled Study of Immunochemotherapy with OK-432 after Curative Surgery for Gastric Cancer," Journal of Immunotherapy, Vol. 27, No. 5, 2004, pp. 394-397. doi:10.1097/00002371-200409000-00008

[123] J. Sakamoto, S. Teramukai, H. Nakazato, et al., "Efficacy of Adjuvant Immunochemotherapy with OK-432 for Patients with Curatively Resected Gastric Cancer: A MetaAnalysis of Centrally Randomized Controlled Clinical Trials," Journal of Immunotherapy, Vol. 25, No. 5, 2002, pp. 405-412. doi:10.1097/00002371-200209000-00004

[124] J. A. Ajani, J. R. Hecht, L. Ho, et al., “An Open-Label, Multinational, Multicenter Study of G17DT Vaccination Combined with Cisplatin and 5-Fluorouracil in Patients with Untreated, Advanced Gastric or Gastroesophageal Cancer: The GC4 Study," Cancer, Vol. 106, No. 9, 2006, pp. 1908-1916. doi:10.1002/cncr.21814

[125] K. Kono, A. Takahashi, F. Ichihara, et al., "Prognostic Significance of Adoptive Immunotherapy with TumorAssociated Lymphocytes in Patients with Advanced Gastric Cancer: A Randomized Trial," Clinical Cancer Research, Vol. 8, No. 6, 2002, pp. 1767-1771.

[126] Y. Wu, L. Wang and Y. Zhang, "Dendritic Cells as Vectors for Immunotherapy of Tumor and Its Application for Gastric Cancer Therapy," Cell \& Molecular Immunology, Vol. 1, No. 5, 2004, pp. 351-356.

[127] J. H. Zhang, M. X. Wan, B. R. Pan, et al., "Cytotoxicity of HSVtk and hrTNF-alpha Fusion Genes with IRES in Treatment of Gastric Cancer," Cancer Biology \& Therapy, Vol. 3, No. 11, 2004, pp. 1075-1080. doi: $10.4161 /$ cbt.3.11.1174

[128] S. Y. Guo, Q. L. Gu, Z. G. Zhu, et al., "TK Gene Combined with mIL-2 and mGM-CSF Genes in Treatment of Gastric Cancer," World Journal of Gastroenterology, Vol. 9, No. 2, 2003, pp. 233-237.

[129] F. Brivio, L. Fumagalli, P. Lissoni, et al., "Pre-Operative Immunoprophylaxis with Interleukin-2 May Improve Prognosis in Radical Surgery for Colorectal Cancer Stage B-C," Anticancer Research, Vol. 26, No. 1B, 2006, pp. 599-603.

[130] F. Brivio, P. Lissoni, R. Gilardi, et al., "Abrogation of Surgery-Induced Decline in Circulating Dentritic Cells by Subcutaneous Preoperative Administration of IL-2 in Operable Cancer Patients," Journal of Biological Regu- 
lators and Homeostatic Agents, Vol. 14, No. 3, 2000, pp. 200-203.

[131] F. Brivio, P. Lissoni, G. Alderi, et al., "Preoperative Interleukin-2 Subcutaneous Immunotherapy May Prolong the Survival Time in Advanced Colorectal Cancer Patients," Oncology, Vol. 53, No. 4, 1996, pp. 263-268.

[132] D. Morgan, F. Ruscetti and R. Gallo, "Selective in Vitro Growth of T Lymphocytes from Normal Human Bone Marrows," Science, Vol. 193, No. 4257, 1976, pp. 10071008. doi:10.1126/science. 181845

[133] K. A. Smith, "Interleukin-2: Inception, Impact and Implications," Science, Vol. 240, No. 4856, 1998, pp. 11691176. doi:10.1126/science. 3131876

[134] S. A. Rosenberg, M. T. Lotze, L. M. Muul, et al., “A Progress Report on the Treatment of 157 Patients with Advanced Cancer Using Lymphokine-Activated Killer Cells and Interleukin-2 or High Dose Interleukin-2 Alone," The New England Journal of Medicine, Vol. 316, No. 15, 1997, pp. 889-897.

[135] J. A. Kovacs, M. Baseler, R. J. Dewar, et al., "Increases in CD4 T Lymphocytes with Intermittent Courses of Interleukin-2 in Patients with Human Immunodeficiency Virus Infection. A Preliminary Study," The New England Journal of Medicine, Vol. 332, No. 9, 1995, pp. 567-575. doi:10.1056/NEJM199503023320904

[136] Y. Levy, C. Capitant, S. Houhou, et al., "Comparison of Subcutaneous and Intravenous Interleukin-2 in Asymptomatic HIV-1 Infection: A Randomised Controlled Trial. ANRS 048 Study Group," The Lancet, Vol. 353, No. 9168, 1999, pp. 1923-1929. doi:10.1016/S0140-6736(98)07345-0

[137] E. L. Jacobson, F. Pilaro and K. A. Smith, "Rational Interleukin 2 Therapy for HIV Positive Individuals: Daily Low Doses Enhance Immune Function without Toxicity," Proceedings of the National Academy of Science of the United States of America, Vol. 93, No. 19, 1996, pp. 10405-10410. doi:10.1073/pnas.93.19.10405

[138] W. G. Cheadle, M. J. Hershman, S. R. Wellhausen, et al., "HLA-DR Antigen Expression on Peripheral Blood Monocytes Correlates with Surgical Infection," The American Journal of Surgery, Vol. 161, No. 6, 1991, pp. 639-645. doi:10.1016/0002-9610(91)91247-G

[139] A. M. M. Eggermont, E. P. Steller and P. H. Sugerbacker, "Laparotomy Enhances Intraperitoneal Tumour Growth and Abrogates the Antitumor Effects of Interleukin-2 and Lymphokine-Activated Killer Cells," Surgery, Vol. 102, No. 1, 1987, pp. 71-78.

[140] D. Morgan, F. Ruscetti and R. Gallo, "Selective in Vitro Growth of T Lymphocytes from Normal Human Bone Marrows," Science, Vol. 193, No. 4257, 1976, pp. 10071008. doi:10.1126/science. 181845

[141] K. A. Smith, "Interleukin-2: Inception, Impact and Implications," Science, Vol. 240, No. 4856, 1998, pp. 11691176. doi:10.1126/science. 3131876

[142] C. Grande, J. L. Firvida, V. Navas, et al., "Interleukin-2 for the Treatment of Solid Tumors Other than Melanoma and Renal Cell Carcinoma," Anticancer Drugs, Vol. 17, No. 1, 2006, pp. 1-12. doi:10.1097/01.cad.0000182748.47353.51
[143] T. Repka, E. G. Cbiorean, J. Gay, et al., "Trastuzumab and IL-2 in HER-2 Positive Metastatic Breast Cancer: A Pilot Study," Clinical Cancer Research, Vol. 9, 2003, pp. 2440-2446.

[144] G. F. Fleming, N. J. Meropol, G. L. Rosner, et al., “A Phase I Trial of Escalating Doses of Trastuzumab Combined with Daily Subcutaneous Interleukin-2: Report of Cancer and Leukaemia Group B 9661," Clinical Cancer Research, Vol. 8, No. 12, 2002, pp. 3718-3727.

[145] R. Dagher, L. M. Long, E. J. Read, et al., "Pilot Trial of Tumor Specific Peptide Vaccination and Continuous Infusion Interleukin-2 in Patients with Recurrent Ewing Sarcoma and Alveolar Rhabdomyosarcoma: An Inter-Institute NIH Study," Medical and Pediatric Oncology, Vol. 38, No. 3, 2002, pp. 158-164.

[146] W. Fiedler, W. Kruger, E. Laack, et al., “A Clinical Trial of Edrecolomab, Interleukin-2 and GM-CSF in Patients with Advanced Colorectal Cancer," Oncology Report, Vol. 8, No. 2, 2001, pp. 225-231.

[147] J. A. Sosman, P. Stiff, S. M. Moss, et al., "Pilot Trial of Interleukin-2 with Granulocyte Colony Stimulating Factor for the Mobilization of Progenitor Cells in Advanced Breast Cancer Patients Undergoing High-Dose Chemotherapy," Journal of Clinical Oncology, Vol. 19, No. 3, 2001, pp. 634-644.

[148] R. S. Freedman, A. P. Kudelka, J. J. Kavanagh, et al., "Clinical and Biological Effects of Intraperitoneal Interferon Gamma and Recombinant Interleukin with or without Tumor Infiltrating Lymphocytes in Patients with Ovarian or Peritoneal Carcinoma," Clinical Cancer Research, Vol. 6, No. 6, 2000, pp. 2268-2278.

[149] W. J. Tester, K. M. Kim, R. L. Krigel, et al., "A Randomized Phase II Study of Interleukin-2 with or without Beta-Interferon for Patients with Advanced Non-Small Cell Lung Cancer. A Eastern Cooperative Oncology Group Study (PZ586)," Lung Cancer, Vol. 25, No. 3, 1999, pp. 199-206. doi:10.1016/S0169-5002(99)00054-9

[150] K. R. Meehan, B. Arun, E. A. Gehan, et al., "Immunotherapy with Interleukin-2 and Alpha Interferon after Interleukin-2 Activated Hematopoietic Stem Cell Transplantation for Breast Cancer," Bone Marrow Transplant, Vol. 23, No. 7, 1999, pp. 667-673. doi:10.1038/sj.bmt.1701632

[151] R. Luksch, D. Perotti, G. Cefalo, et al., "Immunomodulation in a Treatment Program Including Pre- and PostOperative Interleukin-2 and Chemotherapy for Childhood Osteosarcoma," Tumori, Vol. 89, No. 3, 2003, pp. 263268.

[152] G. Mantovani, A. Maccio, C. Mulas, et al., "Dose-Intense Phase II Study of Weekly Cisplatin and Epidoxorubicin Plus Medroxyprogesterone Acetate and Recombinant Interleukin-2 in Stage IIIB-IV Non-Small Cell Lung Cancer," Oncology Report, Vol. 9, No. 3, 2002, pp. 661-670.

[153] K. Yoshimura, S. Hazama, N. Iizuka, et al., "Hepatic Arterial Infusion of IL-2 and Chemotherapy for Unresectable Liver Metastases from Colorectal Cancer," Gan To Kagaku Ryoho, Vol. 29, No. 12, 2002, pp. 2117-2120.

[154] Q. G. Fu, F. D. Meng, X. D. Shen, et al., "Efficacy of Intraperitoneal Thermochemotherapy and Immunotherapy 
in Intraperitoneal Recurrence after Gastrointestinal Cancer Resection," World Journal of Gastroenterology, Vol. 8, No. 6, 2002, pp. 1019-1022.

[155] H. C. Toh, S. L. McAfee, R. Sackstein, et al., "High-Dose Cyclophosphamide + Carboplatin and Interleukin-2 Activated Autologous Stem Cell Transplantation Followed by Maintenance Interleukin-2 Therapy in Metastatic Breast Carcinoma. A Phase II Study," Bone Marrow Transplant, Vol. 25, No. 1, 2000, pp. 19-24.

doi:10.1038/sj.bmt.1702091

[156] A. Le Cesne, G. Vassal, F. Farace, et al., "Combination Interleukin-2 and Doxorubicin in Advanced Adult Solid Tumors: Circumvention of Doxorubicin Resistance in Soft tissue Sarcoma?' Journal of Immunotherapy, Vol. 22, No. 3, 1999, pp. 268-277. doi:10.1097/00002371-199905000-00010

[157] C. Angelini, G. Bovo, P. Muselli, et al., "Preoperative Interleukin-2 Immunotherapy in Pancreatic Cancer: Preliminary Results," Hepatogastroenterology, Vol. 53, No. 67, 2006, pp. 141-144.

[158] F. Romano, G. Cesana, M. Berselli, et al., "Biological, Histological, and Clinical Impact of Preoperative IL-2 Administration in Radically Operable Gastric Cancer Patients," Journal of Surgical Oncology, Vol. 88, No. 4, 2004, pp. 240-247. doi:10.1002/jso.20155

[159] M. Kishiwada, Y. Kawarada, H. Taoka, et al., "Management of Advanced Pancreatic Cancer: Staging Laparoscopy and Immunochemotherapy. A New Treatment Strategy," Hepatogastroenterology, Vol. 49, No. 48, 2002, pp. 1704-1706.

[160] T. Yano, K. Sugio, K. Yamazaki, et al., "Postoperative Adjuvant Adoptive Immunotherapy with Lymph NodeLAK Cells and IL-2 for Pathologic Stage I Non-Small Cell Lung Cancer," Lung Cancer, Vol. 26, No. 3, 1999 , pp. 143-148. doi:10.1016/S0169-5002(99)00082-3

[161] V. A. Tarasov, M. V. Filatov, T. V. Kisliakova, et al., "Combined Surgical and Immunotherapeutic Treatment of Patients with Fourth Stage Colon Cancer," Hybridoma, Vol. 18, No. 1, 1999, pp. 99-102. doi:10.1089/hyb.1999.18.99

[162] N. J. Lygidakis, A. E. Berberabe, N. Spentzouris, et al., "A Prospective Randomized Study Using Adjuvant Locoregional Chemoimmunotherapy in Combination with Surgery for Pancreatic Carcinoma," Hepatogastroenterology, Vol. 45, No. 24, 1999, pp. 2376-2381.

[163] G. Melioli, G. B. Ratto, M. Ponte, et al., "Treatment of Stage IIIB Non-Small-Cell Lung Cancer with Surgery Followed by Infusion of Tumor Infiltrating Lymphocytes and Recombinant Interleukin-2: A Pilot Study," Journal of Immunotherapy, Vol. 19, No. 3, 1996, pp. 224-230. doi:10.1097/00002371-199605000-00007

[164] G. C. Cesana, F. Romano, G. Piacentini, et al., "LowDose Interleukin-2 Administered Pre-Operatively to Patients with Gastric Cancer Activates Peripheral and Peritumoral Lymphocytes but Does Not Affect Prognosis," Annals of Surgical Oncology, Vol. 14, No. 4, 2007, pp. 1295-1304. doi:10.1245/s10434-006-9239-x

[165] K. M. Ropponen, M. J. Eskilinen, P. K. Lipponen, et al.,
"Prognostic Value of Tumor Infiltrating Lymphocytes (TILs) in Colorectal Cancer," The Journal of Pathology, Vol. 182, No. 3, 1997, pp. 318-324. doi:10.1002/(SICI)1096-9896(199707)182:3<318::AID-P ATH862>3.0.CO;2-6

[166] E. Wang, M. C. Panelli, V. Monsurro, et al., "A Global Approach to Tumor Immunology," Cell \& Molecular Immunology, Vol. 1, No. 4, 2004, pp. 256-265.

[167] G. Bovo, F. Brivio, A. Brenna, et al., "Pre-Operative Interleukin-2 Immunotherapy Induces Eosinophilic Infiltration in Colorectal Neoplastic Stroma," Pathologica, Vol. 87, No. 2, 1995, pp. 135-138.

[168] D. S. Silberstein, D. D. Schoof, M. L. Rodrick, et al., "Activation of Eosinophils in Cancer Patients Treated with IL-2 and IL-2-Generated Lymphokine-Activated Killer Cells," Journal of Immunology, Vol. 142, No. 6, 1989, pp. 2162-2167.

[169] F. R. Villegas, S. Coca, V. G. Villarrubia, et al., "Prognostic Significance of Tumor Infiltrating Natural Killer Cells Subset CD57 in Patients with Squamous Cell Lung Cancer," Lung Cancer, Vol. 35, No. 1, 2002, pp. 23-28. doi:10.1016/S0169-5002(01)00292-6

[170] J. Friedl, A. Stift, P. Paolini, et al., "Tumor Antigen Pulsed Dendritic Cells Enhance the Cytolityc Activity of Tumor-Infiltrating Lymphocytes in Human Hepatocellular Cancer," Cancer Biother Radiopharm, Vol. 15, 2000, pp. 477-486.

[171] L. Zhang, J. R. Conejo-Garcia, D. Katsaros, et al., "Intratumoral T Cells, Recurrence, and Survival in Epithelial Ovarian Cancer," The New England Journal of Medicine, Vol. 348, No. 3, 2003, pp. 203-213. doi:10.1056/NEJMoa020177

[172] S. Coca, J. Perez-Piqueras, D. Martinez, et al., "The Prognostic Significance of Intratumoral Natural Killer Cells in Patients with Colorectal Carcinoma," Cancer, Vol. 79, No. 12, 1997, pp. 2320-2328. doi:10.1002/(SICI)1097-0142(19970615)79:12<2320::AI D-CNCR5 $>3.0 . \mathrm{CO} ; 2-\mathrm{P}$

[173] F. Pagès, A. Berger, M. Camus, et al., "Effector Memory T Cells, Early Metastasis, and Survival in Colorectal Cancer," The New England Journal of Medicine, Vol. 353, 2005, pp. 2654-2666.

[174] S. Vesalainen, P. Lipponen, M. Taljia, et al., "Histological Grade, Perineural Infiltration, Tumor-Infiltrating Lymphocytes and Apoptosis as Determinants of Long-Term Prognosis in Prostatic Adenocarcinoma," European Journal of Cancer, Vol. 30, No. 12, 1994, pp. 1797-1803. doi:10.1016/0959-8049(94)E0159-2

[175] L. P. Setala, V. M. Kosma, S. Marin, et al., "Prognostic Factors in Gastric Cancer: The Value of Vascular Invasion, Mitotic Rate and Lymphoplasmacytic Infiltration," British Journal of Cancer, Vol. 74, No. 5, 1996, pp. 766772. doi:10.1038/bjc. 1996.434

[176] J. C. Yang, R. M. Sherry, S. M. Steinberg, et al., "Randomized Study of High-Dose and Low-Dose Interleukin2 in Patients with Metastatic Renal Cancer," Journal of Clinical Oncology, Vol. 21, No. 16, 2003, pp. 3127-3132. 